\title{
The Effect of Community Gardens on Neighboring Property Values*
}

\author{
Ioan Voicu ${ }^{\mathrm{a},}$, Vicki Been ${ }^{\mathrm{b}}$ \\ ${ }^{a}$ Furman Center for Real Estate and Urban Policy, New York University, 110 West $3^{\text {rd }}$ St., New York, NY 10012 \\ ${ }^{b}$ New York University School of Law, 40 Washington Sq. South, 314H, New York, NY 10012
}

First Submission: August 3, 2006

\footnotetext{
* The authors would like to thank Caroline Bhalla, XuFeng Chen and Drew Schinzel for their hard work and good spirits in securing and processing the data necessary for the project; Geoff Davenport and the team of students he lead to conduct the garden quality survey (Amanda Garcia, Ilmi Granoff, Keilem Ng, Gila Jones, Josh Frankel, Tammy Kim, Dave Gunton, Margaret Barry, Ansley Samson, Uma Deshmukh, Avery Wentzel, Matthew Johnston, Peter Hyun, Ed Kim, Marissa Soto and Katie Renshaw); Caroline Bhalla, Ingrid Gould Ellen, Sesha Pochiraju, Solomon Greene, Rachel Meltzer, Richard Revesz, Drew Schinzel, and participants in the NYU Law and Economics Workshop, the NYU Colloquium on the Law, Economics and Politics of Urban Affairs, the University of Michigan Law School Law and Economics Workshop, the University of Connecticut Storrs Lecture Series, the Georgia State University 2006 Law Review Symposium, the Furman Center Round Table on Community Gardens, and the 2006 AREUEA Mid-Year Meeting for their helpful critiques of the study. The financial support of the Max and Filomen D'Agostino Research Fund and the Furman Center for Real Estate and Urban Policy is gratefully acknowledged.
}

* Corresponding author. Tel: +1 212998 6262; Fax: +1 212995 4600; E-mail address: voicui@juris.law.nyu.edu 


\title{
The Effect of Community Gardens on Neighboring Property Values
}

\begin{abstract}
Cities across the United States increasingly are debating the best way to use vacant "infill" lots. Advocates for community gardens and other small green spaces are among the major contenders for the space. To allocate the land most efficiently and fairly, local governments need sound research about the value of such gardens and parks to their host communities. At the same time, cities are looking for new ways of financing the provision of public gardens and parks, such as tax increment financing and impact fees. In order to employ such financing mechanisms, both policy concerns and legal constraints require local governments to base their charges on sound data about the impacts green spaces have on the value of the neighboring properties. Despite the clear public policy need for such data, our knowledge about the impacts community gardens and other such spaces have on surrounding neighborhoods is quite limited. This paper estimates the impact of community gardens on neighborhood property values, using rich data for New York City and a difference-in-difference specification of a hedonic regression model. We find that community gardens have, on average, significant positive effects on surrounding property values, and that those effects are driven by the poorest of host neighborhoods. We also find that higher quality gardens have the greatest positive impact.
\end{abstract}

(JEL H23, H43, R0)

Keywords: community gardens; property values; neighborhoods 


\section{Introduction}

In recent years, controversies have erupted in many communities, perhaps most notably New York City, about the use of vacant lots for community gardens. The gardens often are initially warmly welcomed by communities as catalysts for the improvement of troubled neighborhoods, and frequently become treasured by neighborhood residents. When private owners or public agencies then seek to reclaim the lots for development, support for the gardens often is pitted against other social goals, such as affordable housing or other public uses.

In such controversies, advocates for the gardens have advanced many arguments about the value of the community gardens, claiming that gardens stabilize and improve their host neighborhoods, provide a focal point for community organizing and social networks, bring fresh produce to neighborhood where fresh fruits and vegetables often are not available, and provide recreation and therapy for neighborhood residents. Advocates have cited anecdotal evidence that gardens increased the value of neighboring properties and spurred neighborhood revitalization. As proof of the value of such spaces, advocates also have pointed to efforts of several cities to develop small "pocket” parks through initiatives such as New York City's "Green Streets" program.

Little empirical evidence about the effect community gardens have on surrounding properties is available, however, to inform the debates over whether to foster the development of community gardens, or when to replace community gardens with other uses. That gap is surprising, given that the benefits gardens and small urban green spaces provide, relative to alternative uses of the property, have played a key role in controversies over community gardens not just in New York City, but in Boston, St. Louis and many other communities. ${ }^{1}$ The value of gardens and small parks also is central to debates over the desirability of efforts to reduce sprawl by fostering infill development. More generally, local governments across the country face increasing controversy about how much and what types of green space and park land should be provided by the community or by developers proposing to build within a community. Further, neighborhoods and cities increasingly are debating whether to charge developers impact fees to fund the provision of gardens and small parks within a project. The law requires that any such charges be based upon realistic assessments of the need for and value of such spaces. Similarly, local governments need reliable

\footnotetext{
${ }^{1}$ In addition, cities like Berkeley, Chicago, Madison, Philadelphia and Seattle have grappled with how to design programs to promote community gardens and neighborhood parks.
} 
data about the economic impact of different kinds of parks and open space in order to decide whether to employ tax increment financing (TIF) to support the provision of parks and open space. ${ }^{2}$

Despite this critical need for information, relatively little is known about the economic value of gardens, small urban parks and other such green spaces. A number of studies have investigated the link between proximity to parks or other open space and property values, but the results of the studies may not be transferable to the setting in which many community gardens or small urban parks are found because of their focus on relatively low-density development. Further, the existing studies share methodological and data limitations that make it difficult to pinpoint the direction of the causality of any property value differences found.

In this paper, we attempt to fill these gaps, using unique data from New York City and a difference-in-differences specification of a hedonic regression model to estimate the effect of community gardens on neighborhood property values. Impacts are estimated as the difference between property values in the vicinity of garden sites before and after a garden opens relative to price changes of comparable properties farther away, but still in the same neighborhood. We examine whether effects change over time or vary with neighborhood type and garden quality.

We find that the opening of a community garden has a statistically significant positive impact on the sales prices of residential properties within 1000 feet of the garden, and that the impact increases over time. Higher quality gardens have the greatest positive impact. We also find that gardens have the greatest impact in the most disadvantaged neighborhoods. Finally, a simple cost-benefit analysis suggests that the gain in tax revenue generated by community gardens in the 1000-foot ring may be substantial.

The paper is organized as follows. Section II offers a review of relevant literature. Section III describes the models and empirical strategy. Section IV provides a description of the data, and Section V presents results. The paper ends with a summary of the key findings.

\footnotetext{
${ }^{2}$ Under a TIF plan, a community designates a geographic area that is likely to benefit from the provision of open space, issues bonds to finance the purchase of that space, then pays for the debt service on the bonds from the additional property tax revenues resulting from the increased value of properties within the TIF district. For a TIF to be successful, the park or other amenity financed must spur private development and raise property values sufficiently to generate the increased tax receipts necessary for the debt service. Being able to accurately predict the property value impacts that different kinds of open space will have on neighboring property values accordingly is crucial to local governments considering TIF.
} 


\section{Existing Literature}

Although we know of only one other study of the impact that community gardens have on surrounding properties, a number of studies have investigated the link between proximity to parks and other open spaces and property values. These studies vary widely in their methodology, ranging from simple surveys to hedonic modeling or matched pair analysis. They have examined the influence of a wide range of open space types, such as golf courses, greenbelts, wetlands, agricultural spaces, urban parks and playgrounds. The studies that focus directly on parks of various kinds tend to show positive property value impacts. Crompton [3] surveys the older literature, while Hobden, Laughton and Morgan [13] summarize more recent literature. We review here the hedonic studies that focused on the small urban parks or other open spaces most analogous to community gardens.

Bolitzer and Netusil [1] studied the effect of proximity to an open space (public and private parks, cemeteries and golf courses) in Portland, Oregon, using data on 16,402 sales of single family homes between 1990 and 1992. Using a linear model, they found that a home located within 1500 feet ( $71 / 2$ blocks) of a 20 -acre open space (the mean for the public parks in the area) sold for approximately $\$ 2670$ (in 1990 dollars) more than homes that were further from a park. A semi-log model showed that proximity to any open space increased a home's sales price by $1.43 \%$. When the authors estimated the effect of the different types of open space in the study area, however, the increase in value was limited to public parks and cemeteries; private parks had no statistically significant effect on home prices. Because the mean size of the public parks studied was twenty acres, while the mean size of the private parks was almost 4 acres, the finding that private parks did not have a statistically significant effect on neighboring properties is most relevant for our study of community gardens, which have a median size of 6,000 square feet (less than $1 / 4$ acre) in New York City.

Lutzenhiser and Netusil [16] refined the approach taken in Bolitzer and Netusil [1], using the same data from Portland, Oregon. Breaking the types of open space into five categories, they found that "urban parks" (those in which more than 50\% of the area was landscaped or developed for uses such as swimming pools or ball fields) had a statistically significant effect of \$1214 (in 1990 dollars), or $1.8 \%$ of the mean house value, on the value of single family residences within 1500 feet of the park. That effect was far lower than the effect of both "natural area parks" in which 
a majority of the land was preserved in natural vegetation, and golf courses $(\$ 10,648$ and $\$ 8,849$, respectively). The authors estimated that the size of an urban park that would maximize its positive effect on a home's sales price would be 148 acres, almost 600 times larger than the median size of the community gardens in our study.

Espey and Owasu-Edusei [6] used hedonic methods to investigate the effect proximity to 24 neighborhood parks had on the sales prices of single-family homes in Greenville, South Carolina between 1990 and 1999. The authors broke the parks down into four categories. Type I parks ranged from 15,620 to 87,687 square feet and were essentially playgrounds with some grassy areas, but were not "particularly attractive." Type 2 parks were small, attractive parks with playgrounds. Type 3 consisted of attractive medium-sized parks with both sports fields or courts and playgrounds but also some natural areas; and type 4 parks were unattractive medium-sized parks with few amenities and no natural area. Using a semi-log model, the authors found that the Type I parks had a statistically significant negative effect on the sales prices of homes within 300 feet of the park, a significant positive effect of about 15 percent on the sales of houses between 300 and 500 feet, and a significant positive effect of about 6.5 percent on the sales prices of homes located between 500 and 1500 feet of the park. Small attractive parks (Type 2) had a statistically significant positive effect of 11 percent on the sales prices of houses within 600 feet of the park, but no statistically significant effect beyond that.

Pincetl, Wolch, Wilson and Longcore [21] studied a neighborhood 5 miles from downtown Los Angeles in which most of the housing was multi-family, rental buildings. The neighborhood had no parks, but the authors examined the effect of greenery (as measured using aerial photographs) on 260 sales of single-family homes over an 18 month period. The authors found that an $11 \%$ increase in the amount of greenery (equivalent to a one-third acre garden or park) within a radius of 200 to 500 feet from the house increased the sales price of the house by approximately 1.5 percent. $^{3}$

Hobden, Laughton and Morgan [13] used a matched pairs methodology to measure the effect greenways had on adjacent properties. The authors grouped greenways into eight categories, based upon improvements to the greenways, and also distinguished between "small parks" in which

\footnotetext{
${ }^{3}$ A recent working paper by Wachter and Wong [30] focuses on tree plantings in Philadelphia and finds that they have positive and significant impacts on surrounding property values.
} 
the greenway was a narrow strip (often a pathway) of less than 50 percent of the area of the adjacent residential property. Using data from the years between 1980 and 2001, the authors identified 755 matched pairs. They found that adding a greenway increased the sales price of adjacent properties by $2.8 \%$. Where the greenway was defined as a "small park", the greenway increased the values of adjacent properties by $6.9 \%$.

New Yorkers for Parks and Ernst \& Young [20] found, through [what kind of] methodology, that the values of single family homes located near three well-improved parks in Brooklyn, Queens and Staten Island were 8 to $30 \%$ higher than values of homes further from the parks.

Most directly relevant to our research, Tranel and Handlin [29] used Census data for 1990 and 2000 and a difference in difference methodology to assess the neighborhood effects of 54 community gardens in St. Louis, MO. They found that median rent, median housing costs (mortgage payments, maintenance costs and taxes) for owner-occupied housing, and the homeownership rate increased in the immediate vicinity of gardens relative to the surrounding census tracts, following garden opening.

The usefulness of the existing hedonic studies to many local governments is limited in several ways. ${ }^{4}$ First, most of the studies focus on the impacts of open spaces on single-family house values and other neighborhood indicators in relatively low density settings that do not characterize the denser urban neighborhoods in which many controversies about establishing or preserving parks arise. See, e.g., Bolitzer and Netusil [1]; Espey and Owasu-Edusei [6]; Lutzenhiser and Netusil [16]; Tranel and Handlin [29]. Second, none of the hedonic studies examine the effects the open space might have on nearby commercial properties. Third, the existing literature does not attempt, except in the most general way, to account for differences in the quality of the parks or gardens. See, e.g., Espey and Owasu-Edusei [6] (distinguishing between unattractive and attractive parks).

Moreover, in most previous studies, data limitations make it difficult to pinpoint the direction of causality. The existing studies usually employ cross-sectional techniques that compare sales prices and other neighborhood indicators in neighborhoods with open spaces to those in neighborhoods without, but it is difficult to know whether the two groups of neighborhoods truly are comparable. Therefore, their results could be interpreted to suggest that open spaces lead to

\footnotetext{
${ }^{4}$ Some studies attempt to address these limitations using case studies or other methodological approaches. See e.g., New Yorkers for Parks and Ernst \& Young [20]. We discuss here only those studies using hedonic methods.
} 
improvements in the surrounding neighborhood, but could instead mean that such spaces are systematically located in strong neighborhoods. One exception is Tranel and Handlin [29] who employ a difference in difference methodology to study the neighborhood impacts of community gardens. However, when estimating the impact the gardens have on rents and owner-occupied housing costs, they do not control for housing characteristics, thus raising questions about the comparability of the treatment and control areas. Moreover, their analysis is based on only two data points in time, one before and one after garden formation, and thus, it does not control for baseline (pre-existing) trends, nor does it estimate the variation of garden impacts over time. Finally, the existing literature does not address whether differences in the characteristics of the surrounding neighborhood affect the property value impacts of the parks or gardens.

\section{Methodology}

Our main empirical goal is to estimate the impacts of community gardens on neighboring property values. In this section, we outline various hypotheses about how gardens might affect neighborhood property values, and describe our empirical strategy to identify the property value impacts of gardens.

\section{Hypotheses about how gardens might affect neighborhood property values}

In principle, gardens, parks and other open spaces could have both positive and negative impacts on surrounding communities. They may benefit neighbors by providing access to recreational facilities, fostering a sense of community, providing attractive scenery and views for nearby residents and passersby, replacing an eyesore or a location for undesirable behaviors, and improving both the environmental quality and the general quality of life in the neighborhood. On other hand, they may provide a haven for loitering or other undesirable social behavior, or cause noise and congestion. ${ }^{5}$ If the garden is not well maintained, it may be an eyesore. Since housing is fixed in space, and the value of a home is therefore influenced not only by its structural features and

\footnotetext{
${ }^{5}$ Note, however, that some studies claim that urban gardening may, in fact, reduce local crime (Warner and Hansi [31]; Hynes [11]; Murphy [18])
} 
quality but also by its surroundings, these amenities and disamenities associated with gardens could be capitalized into the value of surrounding properties. Commercial property values also may respond to these various garden features, especially if the garden brings visitors that would increase a retail properties' customer base. Nonetheless, we expect to see lesser effects of gardens on commercial property values than on the values of surrounding residential properties, given that the customers and employees of commercial properties likely have a weaker relationship to the neighborhood than do residents. ${ }^{6}$

While garden impacts - both positive and negative - may be largest in adjacent properties, they may well extend some distance, with diminishing magnitude. However, it is not clear, a priori, how the net effect will vary with distance.

Garden effects also may vary with the garden area. Specifically, both the positive and negative externalities are likely to increase with garden area (e.g. larger gardens may provide more recreational facilities but also may be noisier). Thus, it is uncertain, a priori, whether size will have a positive or negative influence on the net effect of the garden.

Additionally, garden impacts may vary over time. For example, benefits may grow over time as more neighborhood residents become familiar with the garden and get involved in various activities taking place at the garden, or as gardens attract an increasing number of customers to the nearby commercial buildings, thus boosting their activity and increasing the attractiveness of doing business in the neighborhood.

The impact of a garden may vary across neighborhoods with different characteristics. As pointed out in several prior studies (Francis, Cashdan and Paxson [7]; Harnick [10]; SaldivarTanaka and Krasny [24], gardens in poor neighborhoods provide an affordable alternative to city parks, which often are located in more affluent neighborhoods and are not easily accessible to poor residents. Therefore, gardens may be more valuable to these residents, leading one to expect larger

\footnotetext{
${ }^{6}$ The implicit assumption underlying this statement is that, compared to neighborhood residents, customers and employees of commercial properties have equivalent or lower valuation of utility from gardens per unit of time exposed to the garden (otherwise, gardens could have larger effects on commercial properties values than on residential property values, even though employees and customers of commercial properties might have only a temporary presence in the neighborhood). This assumption is not unrealistic because residents are likely to enjoy not only the visual aspect (as most passersby do), but also various community-oriented activities, gathering fruits/vegetables, etc. that are not available to visitors.
} 
positive impacts (or smaller negative impacts) on residential property values in lower-income areas.

Garden effects also may vary with the housing tenure of the neighborhood residents.

Homeowners may have stronger economic incentives than renters to organize and garner financial support for the initial development of the garden and its subsequent maintenance, and, in general, to maintain the garden well. This would likely result in higher quality gardens, and assuming that property value impacts would be positively related to the quality of gardens, thus lead to larger positive impacts on residential property values in neighborhoods dominated by homeowners. Additionally, homeowners may tend to be more involved in community oriented activities - like those hosted by community gardens - than renters, either because of the homeowners' financial stake in neighborhood quality or because homeowners tend to stay in their homes for a longer period of time than do renters. On the other hand, homeowners actually may be less interested in community gardens because it is more likely that their properties already include some kind of private yard that fulfils at least some of the functions gardens serve. Because homeowners typically earn higher incomes than renters, they also may have greater access than renters to alternative open spaces and recreational opportunities. Thus, it is not clear a priori what to expect about how garden effects will vary across neighborhoods with different homeownership rates.

Because renters typically earn lower incomes than owners and live in poorer neighborhoods, it is difficult to empirically disentangle the variation in garden impacts along each of the specific neighborhood characteristics outlined above. Thus, as described in more detail below, we only differentiate impacts according to the neighborhood income level, but interpret any differences we may find as the net result of the interplay between income and tenure. ${ }^{7}$

\footnotetext{
7 One might expect to see less variation in the effect gardens have on commercial (as opposed to residential) property values in different kinds of neighborhoods again because the customers and employees of these businesses are likely to be less attached to the neighborhood hosting the garden than are residents.

Garden impacts on commercial values may vary with the type of nearby commercial buildings; for example, one might expect to see larger positive effects on retail stores given that these are the most likely businesses to benefit from the increased pedestrian traffic (potentially) generated by a garden. Unfortunately, our sample of non-retail (i.e., office and industrial) property sales is too small to reliably estimate the variation in garden impacts across different types of commercial buildings.
} 


\section{Baseline Model}

Identifying the neighborhood impacts of community gardens is challenging, primarily because garden sites might not be randomly chosen (gardens might, for example, be sited on property with the lowest value or with the least development potential, or might be sited in neighborhoods with activists or entrepreneurs who are making other improvements as well). Our basic strategy to address those challenges relies on a hedonic regression model with a difference-indifference specification. Hedonic regression models explain the sales price of a property as a function of its structural characteristics (such as lot size and building age) and its neighborhood surroundings. In brief, we compare the sales prices of properties that are within designated distances - such as 1000 feet - of community gardens to prices of comparable properties that are outside the designated ring, but still located in the same neighborhood (defined here as a census tract). ${ }^{8}$ Then we compare the magnitude of this difference before and after the garden is opened. ${ }^{9}$ This "difference-in-difference" in property values is our measure of the impact gardens have on neighborhoods. The difference-in-difference measure avoids having to compare properties near gardens to other properties in different neighborhoods, and accordingly avoids bias that might be introduced by any systematic differences between neighborhoods that host community gardens and other locations around the city.

To be concrete, our basic model - estimated separately for commercial and residential properties - takes the following form:

(1) $\operatorname{lnP}_{\text {icdt }}=\alpha+\beta X_{i t}+\delta_{c} W_{c}+\gamma_{d t} I_{d t}+\rho_{1}$ InRing $_{\mathrm{i}}+\rho_{2}$ InRing $_{i} * D_{i}+\rho_{3}$ PostRing $_{i t}+\rho_{4}$ PostRing $_{i t} * D_{i t}+$ $\rho_{5}$ PostRing_GArea $a_{i t}+\rho_{6}$ PostRing_GArea $_{i t}^{2}+\rho_{7}$ PostRing_GArea $_{i t} * D_{i t}+\rho_{8}$ PostRing_PvtOwn $_{\text {it }}+$

\footnotetext{
${ }^{8}$ A typical city block (North/South blocks between streets) in Midtown Manhattan is about 260 feet long. Thus, the 1,000 -foot ring allows for impacts extending up to roughly four blocks away from the garden. The 1000 foot radius was selected following Bolitzer and Netusil [1] and Netusil [19]. The former assumed, based on discussions with park officials, that the impacts of urban parks may extend to up to 1500 feet; the latter used a 1300 -foot (1/4 mile) radius to capture impacts of parks and other relatively large open areas (golf courses, wetlands, etc.). Since New York City community gardens are relatively small, we chose a somewhat smaller ring size.

${ }^{9}$ Ellen, Schill, Susin, and Schwartz [4] employ a similar methodology to evaluate the impact of investments in selected homeownership developments.
} 
$\rho_{9}$ TPost $_{i t}+\rho_{10}$ TPost $_{i t}{ }^{2}+\rho_{11}$ TPost $_{i t}{ }^{3}+\rho_{12}$ TPost $_{i t} * D_{i t}+\varepsilon_{i t}$,

where $\ln \mathrm{P}_{\text {icdt }}$ is, for residential properties, the $\log$ of the per unit sales price of property $\mathrm{i}$ (for commercial properties, the $\log$ of the sales price of property i) in census tract c, in community district $\mathrm{d}$, and in quarter $\mathrm{t} ;{ }^{10} \mathrm{X}_{\mathrm{it}}$ is a vector of property-related characteristics, including age, size and structural characteristics; $W_{c}$ are a series of census tract fixed effects, which help control for unobserved, time-invariant features of different neighborhoods; $\mathrm{I}_{\mathrm{dt}}$ are a series of dummy variables indicating the quarter and community district of the sale, ${ }^{11}$ which allow for distinct time trends for each of the 51 community districts used in the analysis; ${ }^{12}$ and the remaining covariates are ring variables (described more fully below) that indicate proximity to garden sites. The coefficients to be estimated are $\alpha, \beta, \delta, \gamma$ and $\rho$, and $\varepsilon$ is an error term. Because we measure sales prices as logarithms, the coefficients can be interpreted as the percentage change in price resulting from an additional unit of the independent variable. For the dummy variables, the coefficients can be interpreted approximately as the percentage difference in price between properties with the attribute - say a garage or a corner location - and those without. ${ }^{13}$

\footnotetext{
${ }^{10}$ For the commercial hedonic model, we follow Colwell, Munneke and Trefzger [2] and use price, rather than the more usual price per square foot, as a dependent variable (and include building square footage among the regressors).

Colwell, Munneke and Trefzger [2] point out that the price per square foot approach may be problematic if the functions that describe the values of buildings and land are nonlinear.

${ }^{11}$ Most previous research has assumed that trends in housing prices are constant across a city or metropolitan area, but this seems particularly inappropriate in a city as large and diverse as New York. Schwartz, Susin, and Voicu [28], for instance, find considerable variation in price trends across community districts in New York City.

${ }^{12}$ While specifying the time dummies using an even smaller geographic area - say a census tract - may seem preferable to the community districts, doing so comes at a considerable cost and adds little explanatory power. Put simply, censustract specific time dummies would add approximately 150,000 more dummy variables to the residential sales specification, significantly increasing the number of parameters to be estimated, and greatly reducing degrees of freedom. Moreover, there is little variation in the time dummies within the community districts - an F-test performed for the residential model could not reject the hypothesis that census tract-quarter dummy variables were the same within a community district. Finally, the use of tract-quarter effects is practically impossible in the commercial model because there are very few tract-quarter cells with multiple sales of commercial properties.

${ }^{13}$ More precisely, the coefficient on a dummy variable should be interpreted as the difference in log price between properties that have the attribute and those that do not. Because the difference in log price closely approximates the percentage difference in price when the difference is small enough and because differences discussed in this paper are
} 
Our key variables of interest are the ring variables, which capture the proximity to community gardens. We include three vectors of ring variables - "InRing," "PostRing," and "TPost." Specifically, the InRing variable is a dummy variable that takes on a value of one if the property is located within 1,000 feet of the site of an existing or future garden. Intuitively, the coefficient on the InRing variable captures the baseline difference in sales prices between properties located within a 1,000-foot ring of a garden and those further away, but still in the same neighborhood. ${ }^{14}$ We interact InRing with $\mathrm{D}_{\mathrm{i}}$, the Euclidean distance between property $\mathrm{i}$ and the nearest garden. This interaction term allows us to estimate how the effects of proximity to a garden site vary with distance to the site, within the 1,000-foot ring.

The PostRing dummy variable indicates whether the property is within 1,000 feet of an existing garden. Its coefficient provides the simplest impact estimate. The existing garden area within the ring of the property, PostRing_GArea, (and its square) offers a measure of the marginal effects of additional square feet of garden area. The share of existing garden area in the ring that is privately owned, PostRing_PvtOwn, captures differences in property prices due to differences in land ownership. ${ }^{15}$ Finally, to allow the impact to vary over time, we include a post-completion trend variable, Tpost, its square, and its cube. ${ }^{16}$ Specifically, Tpost equals the number of years between the date of sale and the garden opening date for properties in the 1,000-foot ring. ${ }^{17}$ Note

generally smaller than 10 percent, we use this more intuitive interpretation throughout the paper. The percentage effect of a difference in logs, $b$, is given by $100\left(e^{b}-1\right)$, although this formula is itself an approximation when $b$ is a regression coefficient; see Halvorsen and Palmquist [9] and Kennedy [14].

${ }^{14}$ In preliminary research, we allowed baseline property values to vary also with both the size and the land ownership of the site; however, we didn't find any statistically significant variations along these dimensions and settled on the more parsimonious specification shown here.

${ }^{15}$ Of the gardens we studied, 95 percent are sited on publicly-owned parcels that are leased to local communities for gardening; the rest are located on privately-owned lots. Throughout the paper we use the terms "gardens sited on publicly-owned (privately-owned) land" and "public (private) gardens" interchangeably.

${ }^{16}$ Preliminary investigation of the data suggested that a third degree polynomial would be desirable to capture the general post-opening time trend in house prices in rings. For the commercial model, we only used a linear trend due to a multicollinearity problem induced by the high correlation between the higher order polynomial terms.

${ }^{17}$ To be clear, Tpost equals 1/365 if a sale is located within the ring of a garden and occurs the day after its opening; it equals one if the sale occurs one year after the garden opening; and so on. The environmental disamenities literature has explored alternative ways to specify the decay or acceleration of impacts over time. See Kiel and Zabel [15], for a useful discussion. 
that because we control for the existing garden area within the ring of a sale and the share of this area that is privately owned, as well as for the time elapsed since the garden opened, the PostRing coefficient should be viewed as the fixed impact of a garden sited on publicly-owned land (independent of its size), immediately after its opening.

We also interact the PostRing variable with distance to allow impacts to vary with distance. In addition, by interacting distance with PostRing_GArea and Tpost, we explore how the distance gradient of impacts changes with garden area and over time. ${ }^{18,19}$

As described below, we estimate two alternative models to the basic model in equation (1). First, we estimate a model which allows impacts to vary across neighborhood types. Second, we adapt the model to include information on the quality of gardens.

\section{Heterogeneity of impacts across different neighborhood types}

To evaluate whether the impact of a garden varies across neighborhoods with different characteristics, we first explore the extent to which the impacts of community gardens vary with income levels in a neighborhood. While Schwartz, Ellen, Voicu, and Schill [27] as well as Santiago, Galster, and Tatian [25] find significant differences in the impact of publicly-subsidized housing investments across submarkets, nobody has explored such variation in the context of green spaces, despite its relevance to such policy issues as environmental justice and the equity of municipal service provision. We test for heterogeneity in impacts between low- and high-income areas by interacting all of our ring variables, ring-distance interaction variables and hedonic variables with a dummy variable indicating neighborhood income level. ${ }^{20}$ Following Schwartz, Ellen, Voicu, and Schill [27], we identified two submarkets - defined by community districts -

\footnotetext{
${ }^{18}$ In preliminary work, we also allowed for nonlinear distance gradients by including distance squared terms; since their coefficients were not statistically significant we opted to exclude them from the models shown here.

${ }^{19}$ Although not shown in equation (1), our specification also includes a set of control variables that capture proximity to other gardens that could not be used for impact estimation either due to missing opening date or because the opening date was outside of the period covered by our sales data. If we didn't include these controls and the location of these other gardens were correlated with that of our sample of gardens with valid data, our impact estimates would be biased. ${ }^{20}$ In earlier models, an F-test rejected the hypothesis that the coefficients on property characteristics are similar across neighborhoods.
} 
based on household income information from the 1990 Decennial Census: the low-income submarket consists of community districts with an average household income less than 80 percent of the MSA mean household income and the higher-income submarket includes all the remaining districts. $^{21}$

\section{Garden Quality}

To better understand the effects different types of gardens may have on neighboring property values, we conducted a survey to gather qualitative information on various garden features and then extended our basic model to incorporate this information. In the survey, we focused on a subset of our sample of community gardens - those located in the Bronx. Following on-site visits, we ranked the Bronx gardens on the following criteria: accessibility to the general public, fencing quality and security, cleanliness, landscaping quality, presence of decorations, existence of social spaces, and overall condition of the garden.

For example, the accessibility rating is derived from questions about whether the garden advertises the hours during which it is open to public, whether the garden provides information about how to get involved with community gardening, and whether there are signs announcing the organization sponsoring the garden (see the Appendix for a detailed description of survey questions). If more than half of the answers under a given criterion reflected a favorable opinion, the garden was rated "Acceptable" on that criterion. The rating of the overall condition of the garden was derived from the whole survey questionnaire. Since no garden had less than 6 or more than 23 favorable answers (out of a total of 24 questions), we choose the mid-point of the $(6,23$ ) interval - 14 - as the threshold for "Acceptable" overall condition. To test the sensitivity of our results to alternative measures of overall condition, we also asked the surveyors to provide an overall assessment of the garden, on a scale of 1 to 5 . A rating of 3 or more points was considered "Acceptable". In addition, we constructed continuous measures of overall condition, equal to the number of favorable answers in the survey questionnaire or to the number of points in surveyors' overall assessment. Finally, we considered a "Low / Good / Excellent" quality rating instead of just "Acceptable / Unacceptable".

\footnotetext{
${ }^{21}$ To create submarkets, we matched census tract-level data to community districts.
} 
Using these garden ratings, we then extend our basic model in two ways. First, we include two additional variables - share of existing or future garden area with acceptable overall quality, and share of existing garden area with acceptable overall quality - to control for the overall condition of the garden. ${ }^{22}$

In the second extension, we allow impacts to vary with the garden's rating on each of the six criteria described above. For this, we replace share of existing garden area with acceptable overall quality with six variables representing the shares of existing garden area with acceptable rating on each of the criteria of community access, fencing quality/security, cleanliness, landscaping, decorations, and social spaces.

\section{Alternative Specifications}

The above model controls for pre-existing differences in price levels between properties within 1,000 feet of garden sites and those further away. However, it is possible that the location of gardens might be related in some systematic way to pre-existing trends in house prices.

Community gardens might tend to be established, for example, in micro-neighborhoods that were starting to appreciate, relative to the surrounding area, even before the advent of the gardens. Many gardens are located in some of the most distressed sites in the city, and it is possible that the value of the most distressed areas was rising as prices bottomed out and private developers began to invest. Or it may be that what determines whether a garden is founded is not just the initial position of a neighborhood (e.g., property value levels), but also the levels of social capital the neighborhood enjoys. If so, a garden neighborhood might have enjoyed property value increases, even before the garden was opened, because of the fact that local community activists were pushing for beneficial changes (including but not limited to a garden). Yet a third possibility is that there might have been a change in the population preceding the garden opening (like the arrival of foreign born residents). All these scenarios suggest that what we interpret as garden impacts might simply be a continuation of these prior trends.

\footnotetext{
${ }^{22}$ In sensitivity analysis using the alternative measures of overall condition, we replace these variables either with the shares of garden area of low and excellent quality or with the number of favorable answers (or points in surveyors' overall assessment).
} 
To help mitigate these concerns, in an extension of our main model, we follow Santiago, Galster and Tatian [25] and estimate a specification that includes controls for trends in the relative price of housing in the vicinity of garden sites prior to the garden opening. In this specification, the counterfactual is that the price gap between properties in the vicinity of garden sites and properties in the larger neighborhood would have continued to shrink (or grow) at the pre-opening rate, had no garden been built. This specification differs from equation (1) mainly in that here we add a ringspecific time-trend that measures the overall price trend in the ring (not simply the trend after completion). This variable is defined in much the same way as Tpost is, except that it also applies to properties sold prior to project completion. For example, if a property is sold exactly two years before garden opening, the trend takes the value of -2 . An increase in prices in the ring right before opening may have been related to the gardens themselves, however, because site cleanup and garden development typically precedes the opening of a garden by about one year. ${ }^{23}$ Accordingly, to avoid capturing this garden-related price increase in the prior trend, we additionally include a dummy variable which is equal to 1 if the property is sold during the year immediately preceding the garden opening.

In an additional, more flexible, specification, we divide the ring-specific time-trend into three linear segments (splines), with knot-points at 10 and 6 years prior to garden opening (or 5 years prior to the start of the site clean-up). This specification allows us to more accurately capture trends which are contemporaneous with the garden. ${ }^{24}$ In this specification, the counterfactual that the price difference between properties near gardens and those in the broader neighborhood would have continued to expand or contract regardless of the garden is based on the pre-opening rate of price change during the five-year period preceding the start of the site clean-up.

Another concern is that other activities, unrelated to gardens, may have been taking place in the micro-neighborhoods surrounding the garden sites, around the time of garden openings. Then,

\footnotetext{
${ }^{23}$ Experts on community gardens in New York City advised us that it takes between several months and two years to set up a community garden. Thus, one year seems a reasonable assumption for the average length of time needed to create a garden.

${ }^{24}$ Note, however, that this specification may be overly conservative if the planning of the garden started well in advance of the actual work. In this case, the anticipation of the effect the garden would have on the surrounding community may have resulted in price changes before the start of the garden development and thus, the price appreciation in the years immediately preceding this start may have been caused, at least in part, by the garden itself.
} 
the change in property values that we interpret as the garden impact may be due, at least in part, to these other activities. The difference in difference methodology we use helps to minimize the possibility that other forces are behind any property value impacts we see because that methodology requires that such other forces would have to occur in the same micro-neighborhoods and be triggered at the same time as the opening of the garden to show up in our results. But to further minimize the possibility that other changes in the neighborhoods in which gardens are opened may be causing any property value impacts we attribute to the gardens, we have extended our analysis to address one of the changes most likely to have occurred in the neighborhoods in which gardens were opened. $^{25}$ During our study period, New York City's own capital program, the Ten Year Plan for Housing, funded the construction or rehabilitation of over 200,000 units of affordable housing (see Schill, Ellen, Schwartz and Voicu [26] for a detailed description of the Ten Year Plan programs). Additionally, about 75,000 housing units were created or rehabilitated with federal subsidies (see Ellen, Schill, Schwartz and Voicu [5] for a detailed description of the federal programs). Like community gardens, this assisted housing was most often sited on blighted, cityowned plots of land (Schill, Ellen, Schwartz and Voicu [26], Ellen, Schill, Schwartz and Voicu [5]), so it is possible that assisted housing was impacting some of the same neighborhoods in which gardens were being established.

To account for these housing investments, we enhance our baseline specification with sets of ring variables (InRing, PostRing, PostRing_Units, and TPost) that control for proximity to various types of subsidized housing. ${ }^{26}$ These include city-sponsored projects and housing units sponsored through federal programs such as Public Housing, Section 8, Section 202, Low Income Housing Tax Credit (LIHTC), Section 236, and Below Market Interest Rate (BMIR).

Finally, one may be concerned that our hedonic analysis may yield biased impact estimates if there are relevant property characteristics that are unmeasured or omitted from the regression

\footnotetext{
${ }^{25}$ One could also imagine that a community opening a garden might at the same time undertake a broader range of neighborhood improvement initiatives that would confound any estimates of the property value impact of the garden. However, experts on community gardens in New York City informed us that while garden communities may embark on other neighborhood improvement activities, such activities usually lag behind the formation of the gardens. Gardens become catalysts of community development, as the networks and other social capital formed over gardens are deployed to start fixing schools and housing, organizing neighborhood watches, and serving other community needs.

${ }^{26}$ PostRing_Units represents the number of existing subsidized units within 1000 feet of the sold property.
} 
equation. In this case in particular, it seems possible that the mix of properties that sells in the vicinity of garden sites changes after the garden opening in ways that are not captured by the hedonic variables. Perhaps the "better" properties sell once the garden is set up. If so, then hedonic analysis may overstate the spillover benefits.

To address this concern, we re-estimate our baseline model using a repeat-sales methodology, which relies solely on properties that sold multiple times over the study period. The repeat-sales methodology is equivalent to including fixed effects at the level of the individual property, and thus effectively controls for any time-invariant characteristics of properties (both in terms of neighborhood features and qualities of the housing itself) that may be unobserved (or omitted) in the hedonic equations. The repeat-sales methodology may, however, be less desirable than the hedonic approach due to its inherent selection bias problems (only properties that sell multiple times are included). An additional drawback of the repeat sales approach is that the model yields no estimates of the coefficients on variables that are time-invariant or that change only rarely or slowly, such as the InRing variables or the fixed structural characteristics of housing.

\section{Summary of Data}

To undertake the analysis outlined above, we obtained data from the Council on the Environment of New York City (CENYC) describing all the community gardens in the city. For each garden, this data set indicates the exact location ( $\operatorname{tax} \operatorname{lot}(\mathrm{s}))$, area, opening date, and land ownership. ${ }^{27}$ Our main estimation sample of gardens includes 636 gardens, established between 1977 and $2000 .^{28}$

\footnotetext{
${ }^{27}$ For a majority of the gardens, the opening date recorded in the CENYC data actually represents the date when the first lease for the site was issued by Green Thumb, the city agency in charge of leasing city-owned land at no charge to neighborhood groups for gardening. According to CENYC staff, the actual opening may have occurred either before or, more often, after the first lease was secured. To test the sensitivity of our results to changes in the opening date, we estimated our baseline models using alternative opening dates - the date recorded in the data, and the date recorded in the data $+/-1$ year. Results differ little in response to different dates. We present in the paper the results based on the date recorded in the data (the positive impact estimates are actually slightly smaller when using this date).

${ }^{28}$ The CENYC raw data included 783 gardens. Out of these, we focused on the 636 gardens established between 1977 and 2000. The reason for this selection criterion is that our sales data only covers the period 1974-2003, and it is generally desirable to match a minimum of two to three years of property sales data both before the earliest garden
} 
Since the CENYC database does not contain any qualitative data about the gardens, we inspected a subset of the city's gardens to obtain such information, as noted above. We chose to survey the gardens in the Bronx because Brooklyn had so many gardens that it was impossible to inspect them all, and we feared that gardens in relatively affluent and high-density Manhattan might not be representative of gardens across the City. The Bronx contains a mix of housing and building types, so is more representative of the City's average neighborhood (and the average neighborhood in most large cities across the nation) than is Manhattan. As shown in Table 3A, gardens in the Bronx are smaller, on average, than all New York City gardens, and were somewhat older than all New York City gardens (44.3\% of the Bronx gardens were established before 1991, compared with $38.1 \%$ of all gardens). We have no reason to believe that the relationship between the quality of the garden and its impacts on surrounding property would be different in the Bronx than in the rest of the City.

We deployed teams of students from NYU School of Law and NYU's Robert F. Wagner Graduate School of Public Service to visit these gardens and rank them on such criteria as the garden's accessibility to the general public, how well-maintained the garden appears, whether there are social spaces in the garden, and whether the garden appears to contain trash or other disamenities. We were able to obtain valid information for 86 gardens (out of the 147 Bronx gardens). ${ }^{29}$

We supplemented our data on community gardens with geocoded data from several other sources. First, through an arrangement with the New York City Department of Finance, we obtained a confidential database that contains sales transaction prices for all apartment buildings, condominium apartments and single-family homes, as well as for all industrial, retail and office

opening date and after the latest opening date. This approach ensures that the estimates of both pre- and post-opening levels and trends in prices in the micro-neighborhoods around the garden sites will be representative of all gardens included in the sample. Nonetheless, we also included in the analysis the rest of 147 gardens which were established outside of the 1977-2000 interval or had missing foundation year - but only to control for proximity to them and thus to obtain accurate impact estimates for the gardens on which we focus.

${ }^{29}$ We eliminated from the analysis garden sites which, upon inspection, turned out to not actually host a garden (e.g., the site was vacant or abandoned, or hosted a school playground), as well as gardens for which the surveyor could not obtain reliable information on one or more items of interest. 
buildings over the period 1974-2003..$^{30}$ Our residential sales sample includes 517,791 property sales, spread across 1,799 census tracts. ${ }^{31}$ The commercial sales sample consists of 26,760 sales, spread across 1,679 census tracts. Both because of the long time span of the data and New York City's size, these are very large sample sizes compared with much of the literature.

Second, data on building characteristics were obtained from an administrative data set gathered for the purpose of assessing property taxes (the RPAD file). Unfortunately, the RPAD data contains little information about the characteristics of individual units in apartment buildings (except in the case of condominiums). ${ }^{32}$ Nonetheless, these building characteristics explain variations in prices surprisingly well, suggesting the data are rich enough for estimating hedonic price equations. ${ }^{33}$

Third, we use demographic data about the neighborhoods from the 1980 U.S. Census to compare the characteristics of neighborhoods in which gardens were opened to those of other neighborhoods. Because most of the gardens were opened since 1980, the 1980 Census data seemed most appropriate.

Finally, we utilize data on the location and characteristics of most federally- and cityassisted housing in New York City from a variety of sources. ${ }^{34}$ We obtained address-specific data from HUD USER on the number of units created through the Section 8 project-based, Section 202,

\footnotetext{
${ }^{30}$ Note that sales of cooperative apartments are not considered to be sales of real property and are not included in the DOF data set. We are in the process of obtaining, from another source, data on most cooperative sales in the city; we'll then add these sales to our estimation sample.

Most of the apartment buildings in our sample are rent stabilized. Given that legally allowable rents were typically above market rents outside of affluent neighborhoods in Manhattan and Brooklyn during the period of our study, we do not believe that their inclusion biases our results (see Pollakowski [22]).

${ }^{31}$ We limited the analysis to properties that are located within the 51 community districts (of the total 59) with community gardens.

32 Most of the RPAD data we use were collected in 1999, and it is conceivable that some building characteristics may have changed between the time of sale and 1999. However, most of the characteristics that we use in the regressions are fairly immutable (e.g., corner location, square feet, presence of garage), and when we merged RPAD data from 1990 and 1999, we found that characteristics changed very rarely. Even among these apparent changes, we suspect that a majority are corrections, rather than true changes.

${ }^{33}$ See Ellen, Schill, Schwartz and Susin [4] for more detail on the data and parameter estimates on the building characteristics in a similar model.

${ }^{34}$ For more details on the subsidized housing datasets used in this paper, see Ellen, Schill, Schwartz and Voicu [5].
} 
LIHTC, BMIR and the Section 236 programs. From the New York City Housing Authority (NYCHA), we secured address-specific data on all public housing developments. New York City's Department of Housing Preservation and Development (HPD) provided address-specific data describing all of the city-assisted housing built between 1977 and 2000.

As mentioned above, identifying properties in the vicinity of garden sites was critical to our analyses. We used GIS techniques to measure the distance between garden sites and each property for which a sale appeared in our database. From these distance measures, we created a variable that identified properties within 1,000 feet of a garden. A continuous distance variable indicates the distance from the property sold to the closest garden site. ${ }^{35}$

Table 1 shows summary statistics for our sales samples. The first panel shows statistics for the residential sales and the second panel describes the sample of commercial sales. In each panel, the first column shows the characteristics of our full sample of property sales; the second column shows the characteristics of transacting properties that were located or in the future would be located within 1,000 feet of a garden. Fifteen percent of the residential sales and 23 percent of the commercial sales were located within 1,000 feet of a garden site. As shown, most of the sales in our samples were located in Brooklyn and Queens, largely because those boroughs include a relatively large share of smaller properties, which sell more frequently than larger ones. Over two thirds of all residential buildings sold were either one- or two-family homes, and 87 percent were single-family homes, two-family homes, or small apartments. In the commercial sales sample, retail properties account for almost 70 percent of all sales, industrial buildings for approximately 25 percent, and office buildings for less than $7 \%$.

The second column in each panel reveals some systematic differences between the transacting properties located close to garden sites and those that are not. Residential properties located within the 1,000-foot ring were more likely to be in Brooklyn and Manhattan than in the

\footnotetext{
${ }^{35}$ Since all tax lots in New York City have been geocoded by the New York City Department of City Planning we used a "cross-walk" (the "Geosupport File") which associates each tax lot with an x,y coordinate (i.e. latitude, longitude using the US State Plane 1927 projection), community district and census tract. In the case of physical structures, a tax lot is usually a building and is an identifier available to the property sales and RPAD data. We are able to assign x,y coordinates and other geographic variables to over 98 percent of the sales using this method. The community gardens data also include the tax lot(s) occupied by each garden, so we were able to assign $\mathrm{x}, \mathrm{y}$ coordinates to each garden lot by the same method. If a garden encompassed multiple lots, we calculated the coordinates of the center of the garden.
} 
other boroughs. They were also older, less likely to be single-family homes, and more likely to be walk-up apartments. Commercial properties within 1000 feet of gardens were more likely to be in Brooklyn, the Bronx or Manhattan than in Queens of Staten Island; and they were also older.

In an effort to better describe the small neighborhoods that host community gardens, we replicated the above comparisons using all properties in rings, not just those that sold. The same picture emerged using these statistics (available upon request from the authors). We also present in Table 2 statistics on the presence of publicly-subsidized housing in the vicinity of garden sites. This table shows that the share of each type of assisted housing - except Mitchell Lama - in the total housing stock in the rings around garden sites is much larger than the share outside the rings. For example, 14.1 percent of the housing stock in rings consists of public housing units, but only 7.1 percent of the total city housing stock is public housing. Subsidized housing in the aggregate accounts for 46 percent of the housing stock in rings, but only for 24 percent of the total stock.

Table 3 shows descriptive statistics for the sample including all of New York City gardens formed between 1977 and 2000, as well as for the sub-sample of Bronx gardens covered by our survey. Whereas the mean area of the city's gardens is 35,000 sq. $\mathrm{ft}$, the median area is only 6,000 sq. ft., suggesting that the area distribution is highly skewed to the right. Most of the gardens are relatively new - 62 percent were established within the last decade - , and the overwhelming majority (95 percent) are sited on publicly-owned land. Most of the gardens are located in Brooklyn, Manhattan and the Bronx, with Brooklyn exhibiting the highest concentration (43 percent). The gardens we surveyed regarding quality are remarkably similar to the whole New York City sample in terms of median area, completion year, and land ownership.

Table 4 compares the average 1980 characteristics of census tracts that include gardens to those that do not have a garden but are in a sub-borough area that does have at least one garden. ${ }^{36}$ It shows that gardens were generally located in distressed neighborhoods. ${ }^{37,38}$ As compared to the

\footnotetext{
${ }^{36}$ We only use sub-boroughs with gardens for these statistics because our subsequent estimation of the garden impacts on property values is based only on these areas (recall from footnote 22 that we limited the analysis to properties that are located within the community districts with community gardens; sub-borough area boundaries are, in general, fairly similar to community district boundaries, and, in addition, they match exactly with census tract boundaries).

${ }^{37}$ The census tract data is taken from the 1980 Census. Tracts are characterized as including gardens even if these gardens did not open until later in the decade.

${ }^{38}$ We use 1980 tract characteristics because Table 2 shows that the vast majority of the gardens in our study were built
} 
average census tract without gardens, tracts with gardens had much lower mean family incomes, much higher poverty rates (twice as high) and unemployment rates, lower educational attainment, much lower homeownership rates (2.5 times lower), and higher vacancy rates. The tracts with gardens housed much greater shares of Hispanic and Black residents than the average tract without gardens. Finally, other demographic statistics indicate that the garden neighborhoods had smaller shares of foreign-born population, a younger population, and smaller shares of residents with stable neighborhood tenure.

\section{Results}

\section{Baseline Model}

Table 5 shows the key coefficients and their standard errors for our baseline model in equation (1). The first column presents the results for the residential sales model and the second column shows the results for the commercial sales model. Coefficients for structural variables are shown in the appendix, Table A1. The relatively high $\mathrm{R}^{2}$ 's $(0.86$ for the residential model and 0.78 for the commercial model), together with the fact that the coefficients on the structural variables are consistent with expectations, suggest that these variables provide adequate controls for the characteristics of the properties sold.

Looking at the estimates of the residential model, the first thing to notice is that the coefficient for the InRing variable (coded " 1 " if the property is within 1,000 feet of the site of an existing or future garden) is negative and statistically significant. In particular, prior to the date the garden was opened, residential properties located right next to a garden site $(\mathrm{D}=0)$ sold for 11.1 percent less than comparable properties located outside the 1,000-foot ring. Anecdotal evidence suggests that sites on which gardens were built often were rubble-strewn sites that were havens for crime and other disamenities. The negative effect the lots had on neighboring property values prior

during the last two decades. Thus, the table largely captures characteristics of the tracts before the gardens were opened. 
to the lots' development as gardens is consistent with that evidence. ${ }^{39}$

The coefficient for the Post Ring variable (coded 1 if the property sold was within 1000 feet of a garden) is positive and statistically significant. Its magnitude is 3.6 percentage points, indicating that the gap between prices in the ring and those outside the ring but in the same census tract narrowed after the garden was established. ${ }^{40}$ Before the garden opened, the gap between properties adjacent to the garden site and out-of-ring properties was 11.1 percent; after the garden opened, this gap fell by 3.6 percentage points, to 7.5 percent.

Tpost measures the number of years between the opening of the garden and the property sale. The coefficients on TPost and its square are positive and significant, whereas the coefficient on Tpost ${ }^{3}$ is negative and significant. This implies that the positive impacts gardens have on surrounding properties grow over time at a (slightly) increasing rate up to some point, beyond which the growth continues at a decreasing rate. The garden's increasing value to the neighborhood may result from greater certainty about the garden's maintenance, or perhaps may reflect neighbors' increasing awareness of, or involvement in, the garden. It also is consistent with the possibility that the gardens serve as catalysts of community development (see footnote 25 above). In the first year after the garden opens, the positive impact increases by 0.6 percentage points, and subsequent years bring additional, and increasingly larger, positive impacts. Ten years after opening, the growth starts slowing down, and it appears to stop 15 years later (i.e., 25 years after opening). The negative

\footnotetext{
${ }^{39}$ The coefficient for the InRing*D variable is positive and significant, indicating a sharp price gradient such that the pre-garden price-depressing effects of the site (the disamenity) decline with distance. For example, at a distance of 1,000 feet, residential prices are only 1 percent lower, meaning that the price differential falls at a rate of about 1 percentage point per 100 feet.

${ }^{40}$ As noted before, the Post Ring coefficient provides an estimate of the fixed component of the public garden effect that is, the portion of the impact that is independent of the garden area. Increasing garden size appears to bring a smaller benefit, perhaps because larger gardens tend to be noisier and to generate more congestion. However, this negative marginal effect of garden area is fairly small and declines as the area increases. To take a concrete example, a 10,000 sq. $\mathrm{ft}$ increase in garden area, from 1000 to 11,000 sq. $\mathrm{ft}$, reduces the external benefit by only 0.2 percentage points. Spillover benefits are also negatively affected by the private ownership of the land on which the garden is sited. The benefit of a privately-owned garden is 2.8 percentage points lower than that of similar garden sited on publiclyowned land, and it is not statistically significant. Finally, note that the coefficients on PostRing*D and PostRing GArea $* \mathrm{D}$ are not statistically significant, suggesting that impacts vary little with distance from the site right after garden opening.
} 
and significant coefficient on the interaction between Tpost and distance suggests that impacts increase less over time farther away from the garden.

Estimates of the gardens' impact on commercial property values, shown in the second column of Table 5, present a much different picture. Again, the lots on which gardens will eventually be placed have a significant and negative effect on surrounding commercial property values before the garden is established, indicating that the vacant lot or other pre-garden use was a serious disamenity. The opening of a garden, however, has no immediate effect on surrounding commercial properties (the PostRing coefficient is not statistically significant). A rise in property values may occur over time, however, as suggested by the positive and significant TPost coefficient - perhaps as gardens attract additional customers to the nearby commercial buildings, thus increasing the attractiveness of doing business in the neighborhood.

Figure 1 and Table 6 show estimated impacts on residential property values for a typical New York garden with an area of 6,000 sq.ft. - the median garden size in our sample. ${ }^{41}$ The thick line in Figure 1 shows the percentage difference between prices in the ring and prices in the surrounding neighborhood, before the garden was established. As noted, this pre-garden gradient is fairly steep, climbing at a rate of 1 percentage point per 100 feet, such that sales prices for property nearest to the site are 11.1 percent lower than prices for properties outside the 1000 foot ring.

The thinner lines above that baseline show price gradients one, three, and five years after garden opening and suggest substantial impacts, especially for the housing closest to the garden. Before the garden opens, prices in the immediate vicinity of the garden site are 11.1 percent lower than in the surrounding neighborhood; in the first year after opening this gap falls by 4.1 percentage points, to 7 percent. ${ }^{42}$ Over the five-year period after opening, the gap falls by 7.4 percentage points, to only 3.7 percent. Note that at 1,000 feet, impacts are smaller, ranging from 1.5 percentage points

\footnotetext{
${ }^{41}$ We use the median rather than the mean garden size to define the typical garden because our sample distribution of garden area is highly skewed to the right (e.g., the mean is larger than the $80^{\text {th }}$ percentile).

${ }^{42}$ The difference between the 3.6 percentage point impact reported in Table 5 and the 4.1 percentage point impact reported in this simulation results partly from our using a garden of the median size in our sample for the simulation. An additional reason for this discrepancy is that the former number represents the impact immediately after garden opening whereas the latter represents the impact one year after opening.
} 
one year after the garden opening to 1.9 percentage points five years after opening. ${ }^{43}$

Table 6 also includes the dollar-value of garden impacts, estimated by applying the percentage-point impacts to the median real sale price - expressed in 2003 dollars - for housing in the 1000 -foot rings around gardens $(\$ 88,031) .{ }^{44}$ For example, in the immediate vicinity of the garden, the dollar-value impact is $\$ 3,607$ one year after opening, and grows to $\$ 6,551$ five years after opening.

In summary, we find that gardens were located on sites that acted as local disamenities within their communities. After opening, gardens have a positive impact on surrounding residential property values, which grows steadily over time, and declines somewhat with garden area, and distance to the garden. ${ }^{45}$ Gardens do not appear to have any significant immediate impacts on neighboring commercial property values, although benefits may occur over time.

\section{Heterogeneity of impacts across different neighborhood types}

The first two columns of Table 7 report the results of the residential model in which impacts are allowed to vary between lower and higher income submarkets. Coefficients in column (1) capture impacts in higher-income submarkets; coefficients in column (2) capture the difference between the impacts in low- and higher-income submarkets.

The estimates reveal significant differences in garden impacts between the low and higher income neighborhoods. The coefficient for the PostRing variable (indicating that the property is within 1000 feet of a site on which a garden has been established) is not statistically significant in

\footnotetext{
${ }^{43}$ Note however that these estimates likely understate impacts at 1000 feet because the coefficients on the interactions of PostRing and Garden area with distance are not statistically significant, and yet we included them in predictions. Discarding the insignificant coefficients yields impact estimates at 1000 feet that vary between 3.3 percentage points one year after opening to 3.8 percentage points five years after opening.

${ }^{44}$ We use median rather than mean price in our simulations because the citywide mean house price is driven up by the hot submarkets in Manhattan and certain areas of Brooklyn. Nonetheless, in Table A2 in the appendix, we also show the less conservative dollar-value impact estimates based on the mean housing price in rings $(\$ 125,275)$. Right next to the garden, these estimates range from $\$ 5,134$ one year after opening to $\$ 9,323$ five years after opening.

${ }^{45}$ Impact also declines with private ownership of the land on which the garden is sited.
} 
higher-income areas, but it is positive, significant, and relatively large in low-income areas. ${ }^{46}$ These differences suggest that, while there is little positive impact of gardens in higher-income neighborhoods (at least not soon after opening) gardens are likely to generate significant and sustained benefits in poorer neighborhoods. ${ }^{47}$ We estimate that the price differential between a property located right next to a typical garden and a comparable property located outside the ring falls by 6.2 percentage points one year after a garden opens in low-income submarkets. This translates into a dollar-value of $\$ 5,421$ (based on the city-wide median price). Five years after the garden opens, the impact is even larger: 9.4 percentage points or $\$ 8,300$ (again, based on the citywide median price). Again, impacts are smaller farther away from the garden, at 1000 feet away ranging from 1.3 percentage points one year after opening to 2.1 percentage points five years after opening (see appendix, Table A3 for more detailed estimates).

The finding that community gardens bring significantly larger benefits in lower-income neighborhoods is not surprising. As pointed out in several prior studies (Francis, Cashdan and Paxson [7]; Harnick [10]; Saldivar-Tanaka and Krasny [24]), gardens in poor neighborhoods provide an affordable alternative to city parks, which are usually located in more affluent neighborhoods and are not easily accessible to poor residents. Moreover, the residents of lowerincome neighborhoods are predominantly renters who, for reasons noted earlier, may be more interested in gardens than homeowners. ${ }^{48}$

Given that subsidized housing doesn't sell often or at all (like public housing), that it makes up a significant share of the housing stock in the rings around gardens (as shown in Table 2), and that it is heavily concentrated in the poor neighborhoods where the gardens bring larger benefits, our average impact estimates for the city as a whole (from Table 5) may be downward biased. ${ }^{49}$

\footnotetext{
${ }^{46}$ Additionally, in low-income neighborhoods, the negative marginal effect of additional garden area is significantly smaller than in higher income neighborhoods.

${ }^{47}$ Note, however, that even in higher income areas benefits may arise over time, as suggested by the positive and significant TPost $^{2}$ coefficient.

${ }^{48}$ We alternatively hypothesized at the outset that homeowners may have stronger economic incentives than renters to create higher quality gardens, but we didn't find a statistically significant correlation between garden quality and the homeownership rate in the garden neighborhood.

${ }^{49}$ See Schill, Ellen, Schwartz and Voicu [26] and Ellen, Schill, Schwartz and Voicu [5] for comprehensive evidence that subsidized housing is concentrated in poor neighborhoods.
} 
In the commercial model, shown in the last two columns of Table 7, we find virtually no difference in the neighborhood impacts of gardens for low income and higher income neighborhoods. The impacts of the gardens are statistically insignificant in both types of neighborhoods.

\section{Garden Quality}

We were unable to rate the quality of all the gardens in our sample, so we focused our quality survey on gardens in the Bronx. Our analysis of whether and how quality matters, therefore must use estimates of our baseline specification based on the surveyed Bronx gardens only. These estimates are presented in Table 8 . The results for the residential model, shown in the first column, are in line with our general findings - gardens have a statistically significant positive effect on inring properties. The results also are consistent with our analysis of the neighborhood heterogeneity of impacts - that is, the positive impacts of gardens are larger in lower income areas, such as the Bronx. Note however that in the Bronx model, the positive PostRing coefficient and the negative coefficients of PostRing*D and Garden area are substantially larger than the low-income submarket coefficients estimated for the whole city. These suggest that the positive impacts of Bronx gardens, although very large for small gardens and in the immediate garden proximity, decline relatively quickly with garden area and distance to the garden.

Estimates of the commercial model based on the surveyed gardens are shown in the second column of Table 8, and are consistent with our previous findings that gardens have little impact on commercial property values.

The garden quality measures summarized in Table 3 show that between 60 and 77 percent of the surveyed gardens (depending on the assessment method) have acceptable overall condition. About two thirds of the surveyed gardens have acceptable community access and fencing quality/security; more than half are acceptable in terms of cleanliness and have some sort of (nonseasonal) decorations; a large majority (93 percent) have acceptable landscaping; and relatively few gardens (35 percent) have some kind of social gathering spaces.

We next turn to the results of several extensions of the baseline model that include variables describing the quality of gardens. First, we focus on the estimates of a specification that includes the "Acceptable / Not Acceptable" measure of the overall garden condition. Table 9 presents these 
estimates for both the residential and commercial sales samples. As shown in the second column of this table, our estimate of the effect of the overall garden condition on commercial property values is not statistically significant, so our discussion will focus on the residential properties.

The coefficients of the residential model recorded in column (1), reveal first that gardens with acceptable overall condition were built in relatively more distressed neighborhoods than gardens with unacceptable overall condition. Specifically, the InRing coefficient shows that prior to the garden opening, properties located right next to a site that would host a low-quality garden sold for 6.5 percent less than comparable properties located outside the 1,000-foot ring (but still in the same census tract). ${ }^{50}$ By comparison, for sales adjacent to sites that will ultimately hold goodquality gardens, estimated prices initially were 14.5 percent lower than in the surrounding neighborhood. ${ }^{51}$ These disamenity effects decline with distance to the site, as shown by the positive InRing*D coefficient.

The PostRing coefficient, which quantifies the fixed effect of a low-quality garden, is positive, has a magnitude of 5 percentage points but is only weakly significant, at the 11 percent level. By comparison, the (fixed) effect of a good-quality garden - given by the sum of the coefficients on PostRing and Share of existing garden area with acceptable quality - is 12.8 percentage points and is highly significant, suggesting that garden quality plays an important role in its impacts. As noted earlier, impacts decline significantly with garden area and distance to the garden, but increase over time.

Again, simulations are helpful to summarize results. The impact of a low-quality garden of typical size on the properties located in its immediate vicinity is 5 percentage points and is statistically significant at the 10 percent level, whereas that of a good-quality garden of similar size is 12.8 percentage points and highly significant. ${ }^{52}$ As distance to the garden increases, however, the positive impact of low-quality gardens vanishes (at around 440 feet) and is transformed into an increasingly negative effect. The positive impact of good-quality gardens, diminishes, too, with distance, and at 1000 feet is statistically insignificant.

\footnotetext{
${ }^{50}$ In this discussion, we are using interchangeably the terms "acceptable (unacceptable) condition" and "good (low)quality"

${ }^{51}$ The 14.5 percent is obtained by adding up the coefficients on the InRing and the Share of existing/future garden area variables.

${ }^{52}$ These estimates are computed at one year after garden opening.
} 
These results are robust across specifications using alternative measures of the overall garden condition (described in the methodology section above). The estimates of these alternative specifications are presented in the appendix, Tables A4 and A5.

Table 10 presents results of specifications that focus on specific aspects of garden quality identified in the survey - community access, fencing quality/security, cleanliness, landscaping, decorations, and social spaces. ${ }^{53}$ The results for the residential model reported in the first column show that the features that matter most are fencing quality/security, cleanliness, and landscaping. Ensuring good fencing quality and security boosts the garden's impact by 3 percentage points, on average (relative to the impact of a garden with unacceptable fencing quality and security); acceptable garden cleanliness adds 3.8 percentage points; and acceptable landscaping increases impacts by 5.8 percentage points.

\section{Alternative Specifications}

As noted above, the average price differential between the rings and their census tracts may have already been declining prior to the garden establishment and may have continued to decline, even without the garden. To test for this possibility, we extend our specification to include the trend in housing prices before the garden opens within the ring surrounding what will become a garden. We do indeed find a slight upward trend in residential prices prior to the garden opening. ${ }^{54}$ However, even after controlling for these prior trends in housing prices, we still find significant positive impacts upon garden opening. ${ }^{55}$ In fact, the impact estimates are only slightly smaller than those found in the baseline model. The positive impacts gardens have on residential properties accordingly are not explained by a general upward trend in prices in the ring. For commercial prices, we find, surprisingly, a downward trend in the years prior to the garden opening. This makes

\footnotetext{
${ }^{53}$ As shown in the second column of Table 9, these specific garden features play little role in the garden impacts on commercial property values, so our discussion will, again, focus on the residential properties. The only significant coefficient among the quality variables in the commercial model is that on the share of garden area with decorations. However, given its abnormal magnitude, we believe that this finding may be just a fluke of the data.

${ }^{54} \mathrm{We}$ also find a significant increase in house prices in the year immediately preceding the garden opening, however, as noted above, this increase is likely caused by the garden itself.

${ }^{55}$ These estimates are available upon request from the authors.
} 
the positive TPost coefficient estimate even larger than that obtained in the baseline model.

To account for the possibility that publicly-subsidized housing investments may have systematically occurred at the same times and locations as the community gardens, thus biasing our garden impact estimates, we also estimated models in which we include extensive controls for proximity to various types of subsidized housing. The results remained virtually unchanged, indicating that this scenario is unlikely. ${ }^{56}$

Finally, we estimate a repeat sales specification of the residential baseline model to test for the possibility that our results simply capture the fact that higher quality properties were sold after the garden openings. ${ }^{57}$ We obtain repeat sales estimates that are similar to the hedonic ones; if anything, they yield somewhat larger spillover benefits than the hedonic estimates. ${ }^{58}$

\section{Costs and Benefits of Community Gardens}

The City usually has incurred little or no expense, other than opportunity costs, related to the development and maintenance of the existing community gardens. These costs usually were supported by funds local community groups raised from local sources or from foundations, private individuals, or federal or state government agencies. However, from a policy perspective, it would be informative to consider alternative scenarios in which some or all costs are paid for through public subsidies.

To quantify garden costs, we rely on estimates provided in an earlier study by Fox, Koeppel and Kellam [8]; this study contains perhaps the most comprehensive cost analysis of New York City community gardens. Fox, Koeppel and Kellam [8], who surveyed a large group of community gardens in New York City (over 300 gardens), estimated that the initial capital costs for an average garden $^{59}$, including all one-time expenses ${ }^{60}$ applied to the original development of the site, would

\footnotetext{
${ }^{56}$ These estimates are available upon request from the authors.

${ }^{57}$ It is not feasible to use the repeat sales estimation for the commercial model because the number of repeat sales of commercial properties is too small to yield reliable estimates.

${ }^{58}$ The repeat sales estimates are available upon request from the authors.

${ }^{59}$ The average garden size in Fox, Koeppel and Kellam [8] is 5,225 sq.ft., which is very similar to the median garden size in our study $(6,000$ sq.ft.)
} 
total $\$ 16,365$. $^{61}$ They also estimated an annual maintenance cost (including sweat equity and expenditures on items needed in the garden maintenance) of $\$ 8,683 .{ }^{62}$ To obtain the total garden cost, we add the net present value of the stream of maintenance costs over a 20 -year period to the (one-time) initial capital costs. ${ }^{63}$ In the end, we estimate that a garden would cost, on average, about $\$ 279,000$ (in 2003 dollars) to develop and maintain for twenty years.

To simulate the gross tax revenue gains generated by community gardens, we estimate the aggregate increase in residential property values generated by each garden (within a 1,000-foot radius) and then apply a standard tax assessment formula to these benefits, following the approach in Schwartz, Ellen, Voicu, and Schill [27]. ${ }^{64}$ Specifically, to estimate the aggregate benefits, we undertake a three-step process. First, we use the RPAD database ${ }^{65}$ to identify all the residential properties (whether sold or not) that were located within 1,000 feet of a garden site and thus should have benefited from the garden establishment.

Second, we assign an approximate initial or "pre-opening" price to each of these properties. We calculated, for each year in our data, the median per unit sales price for all properties that sold in that year within 1000 feet of any garden site, prior to the establishment of the garden. The "preopening price" assigned to each property (sold or not) is equal to the above median price that corresponds to the establishment year of the garden within 1000 feet of that property.

Third, we use the pre-opening prices and number of units of each property, the size and land ownership of gardens within 1,000 feet of each property, the distance from each property to the nearest garden site, and our baseline post-opening coefficients, to estimate the increase in property values that should have occurred following garden completion. The sum of these gains over all

\footnotetext{
${ }^{60}$ These initial, one-time expenses cover the clearing of the site, providing a fence, plant materials, lumber of raised beds and benches, signs, technical assistance, and the like.

${ }^{61}$ This dollar value represents 1982 dollars. In 2003 dollars, the cost is $\$ 31,500$.

${ }^{62}$ Again, this dollar value represents 1982 dollars. In 2003 dollars, the annual maintenance cost is $\$ 16,700$.

${ }^{63}$ For the present value calculation, we assume a growth rate in maintenance costs of 4.2 percent (equal to the average inflation rate over the study period), and a discount rate of 5.35 percent (the average for recent city general obligation debt issues). We compute maintenance costs over a 20 -year period because this is the time interval used to estimate tax benefits (see below).

${ }^{64}$ We limit our simulation to residential properties because we did not find much effect of gardens on commercial property values.

${ }^{65}$ The RPAD database is an annual census of all New York City properties, described above.
} 
properties is an estimate of the total benefit that all the gardens delivered to residential properties within a 1,000-foot radius. To be conservative, we assume that the growth in impacts over time (given by the TPost coefficient) ends five years after garden establishment. Given this assumption, we compute total benefits as the net present value of the five annual increments. ${ }^{66}$

Using this three-step method, we estimate that the benefits generated in the 1,000-foot ring total almost $\$ 1.3$ billion (in 2003 dollars) - or $\$ 2$ million per garden. ${ }^{67}$ To measure the corresponding tax revenue gains, we first discount total benefits by a factor of 0.7 since the appraised market values used by the New York City Department of Finance for tax assessment purposes are, on average, about $70 \%$ below sales prices (on which our measured benefits are based). We then estimate the increase in tax revenues in the first year after garden completion by applying the New York City assessment ratios and tax rates to the discounted increases in property values accrued during that year. ${ }^{68}$ Finally, we compute the total tax revenue gains as the present value of the stream of annual tax benefits over a 20 -year period, based on assumptions suggested by the staff of the New York City Independent Budget Office. ${ }^{69}$

In the end, we estimate that the gross tax benefit to the City generated by all community gardens over a 20 -year period amounts to about $\$ 503$ million. If the City had fully subsidized the garden provision, the City's total investment would have amounted to over $\$ 177$, million. Thus, the estimated net tax benefit over 20 years would be, in the aggregate, over $\$ 325$ million or, per garden, about $\$ 512,000$.

\footnotetext{
${ }^{66}$ For this calculation, we assume, again, a temporal discount rate of 5.35 percent.

${ }^{67}$ A comparison between the 1998 assessed values of properties in rings that sold in 1999 and the assessed values of all properties in rings suggests that transacting properties may have higher values than other properties. We thus correct for this selection bias when estimating total benefits.

${ }^{68}$ Assessment ratios and tax rates vary by property type. The Department of Finance groups residential properties into three classes - class 1 (1-3 family houses), class 2 (4-6 family buildings), and class 2A (all the others) - and sets an assessment ratio and a tax rate for each class. The assessment ratio for class 1 is 0.08 , for class 2 is 0.25 and for class $2 \mathrm{~A}$ is 0.45 . The tax rate for class 1 is 0.116 , and for the other two classes is 0.108 . Due to this variation in assessment and tax rates, we also estimate the total benefits from gardens separately for each of the three building classes and then apply the corresponding rates to the benefit for each class.

${ }^{69}$ Specifically, we assume an annual growth of 2.5 percent in property taxes over 20 years, based on average increases in assessments, and a discount rate of 5.35 percent. Note that during the first five years after garden completion, the assumed 2.5 percent annual increase in taxes is over and above the increase due to the growth in garden impacts.
} 


\section{Conclusion}

Our finding that community gardens have, on average, significant positive effects on surrounding property values, and that those effects are driven by the poorest of host neighborhoods (where a garden raises neighboring property values by as much as 9.4 percentage points within five years of the garden's opening) should help local governments make sounder decisions about whether (and how much) to invest in (or to encourage private investment in) community gardens and other green spaces. Such investments have a sizeable payoff for the surrounding community, and ultimately for the city itself, as it realizes additional property tax revenues from the neighborhood.

Our findings also will help local governments considering whether to use tax increment financing (TIF) to estimate the potential benefits of investments in urban parks and gardens. Our results show that such gardens can lead to increases in tax revenues of about half a million dollars per garden over a 20-year period. Finally, local governments may use our results to justify the imposition of impact fees to finance the provision of gardens or urban parks, by showing the benefits the developers' properties will receive as a result of proximity to such spaces.

\section{References}

[1] B. Bolitzer, N.R. Netusil, The impact of open spaces on property values in Portland, Oregon. Journal of Environmental Management 59 (2000) 185-193.

[2] P.F. Colwell, H.J. Munneke, J.W. Trefzger, Chicago's office market: price indices, location and time, Real Estate Economics 26 (1998) 83-106.

[3] J.L. Crompton, J.L., The impact of parks on property values: a review of the empirical evidence, Journal of Leisure Research 33 (2001) 1-31.

[4] I.G. Ellen, M.H. Schill, S.J. Susin, A.E. Schwartz, Building homes, reviving neighborhoods: spillovers from subsidized construction of owner-occupied housing in New York City, Journal of Housing Research 12 (2002) 185-216.

[5] I.G. Ellen, M.H. Schill, A.E. Schwartz, I. Voicu, Does federally subsidized rental housing 
depress neighborhood property values? forthcoming in the Journal of Policy Analysis and Management (2006).

[6] M. Espey, K. Owusu-Edusei, Neighborhood parks and residential property values in Greenville, South Carolina, Journal of Agricultural and Applied Economics 33 (2001) 487-492.

[7] M. Francis, L. Cashdan, L. Paxson, Community Open Spaces. Greening Neighborhoods through Community Action and Land Conservation, Island Press, Washington, D.C., Covelo, California, 1984.

[8] T. Fox, I. Koeppel, S. Kellam, Struggle for Space, Neighborhood Open Space Coalition, New York, NY, 1985.

[9] R. Halvorsen, R. Palmquist, The interpretation of dummy variables in semilogarithmic equations, American Economic Review 70 (1980) 474-475.

[10] P. Harnick, Inside City Parks, Urban Land Institute and Trust for Public Land, Washington, D.C, 2000.

[11] H.P. Hynes, A Patch of Eden, America's Inner-City Gardeners, Chelsea Green, White River Junction, VT, 1996.

[12] P. Herscovitch, Community Gardens, http://www.urban-os.com/project-pool/one?prj_id=3569, 2003.

[13] D.W. Hobden, G.E. Laughton, K.E. Morgan, Green space borders - a tangible benefit? evidence from four neighbourhoods in Surrey, British Columbia, 1980-2001, Land Use Policy 21 (2004) 129-138.

[14] P.E. Kennedy, Estimation with correctly interpreted dummy variables in semilogarithmic equations, American Economic Review 71 (1981) 801.

[15] K.A. Kiel, J. Zabel, Estimating the economic benefits of cleaning up superfund sites: the case of Woburn, Massachusetts, Journal of Real Estate Finance and Economics 22 (2001) 163-184.

[16] M. Lutzenhiser, N. Netusil, The effect of open spaces on a home's sale price. Contemporary Economic Policy 19 (2001) 291-298.

[17] T.A. More, T. Stevens, P.G. Allen, Valuation of urban parks, Landscape and Urban Planning 15 (1988) 139-152.

[18] C. Murphy, Cultivating Havana: Urban Agriculture and Food Security in the Years of Crisis, Food First, Oakland, CA, 1999.

[19] N. R. Netusil, Does ownership matter? examining the relationship between property values and 
privately and publicly owned open spaces, streams and wetlands, Working Paper, Reed College, Department of Economics, 2005.

[20] New Yorkers for Parks and Ernst \& Young, Analysis of Secondary Economic Impacts Resulting from Park Expenditures, 2003.

[21] S. Pincetl, J. Wolch, J. Wilson, T. Longcore, Toward A Sustainable Los Angeles: A 'Nature's Services" Approach, USC Center for Sustainable Cities, Los Angeles, 2003.

[22] H.O. Pollakowski, The Effects of Rent Deregulation in New York City, MIT Center for Real Estate, Cambridge, MA, 1997.

[23] R. Ready, C. Abdalla, GIS Analysis of land use on the rural-urban fringe: the impact of land use and potential local disamenities on residential property values and on the location of residential development in Berks County, Pennsylvania, Pennsylvania State University Department of Agricultural Economics and Rural Sociology Staff Paper 364, 2003.

[24] L. Saldivar-Tanaka, M. Krasny, Culturing community development, neighborhood open space, and civic agriculture: the case of latino community gardens in New York City, Agriculture and Human Values 21 (2004) 399-412.

[25] A.M. Santiago, G.C. Galster, P. Tatian, Assessing the property palue impacts of the dispersed housing subsidy program in Denver, Journal of Policy Analysis and Management 20 (2001) 6588.

[26] M.H. Schill, I.G. Ellen, A.E. Schwartz, I. Voicu, Revitalizing inner city neighborhoods: New York City’s Ten Year Plan for housing, Housing Policy Debate, 13 (2002) 529-566.

[27] A.E. Schwartz, I.G. Ellen, I. Voicu, M.H. Schill, The external effects of place-based subsidized housing, forthcoming in Regional Science and Urban Economics (2006).

[28] A.E. Schwartz, S.J. Susin, I. Voicu, Has falling crime driven New York City's real estate boom? Journal of Housing Research 14 (2003) 101-135.

[29] M. Tranel, L.B. Handlin, Jr., Metromorphosis: documenting change, Journal of Urban Affairs, 28 (2006) 151-167.

[30] S. Wachter, G. Wong, What is a tree worth? green-city strategies and housing prices, Working Paper, The Wharton School, University of Pennsylvania, 2006.

[31] S.B. Warner, D. Hansi, To Dwell is to Garden: A History of Boston's Community Gardens, Northeastern University Press, Boston, 1987.

[32] J.A. Yoegel, An Inquiry into the Impact of Park Land Location Upon Single Family 
Residential Property Values in Middle and Upper Income Communities in Westchester County, New York, Doctoral dissertation, New York University, New York, 1986. 


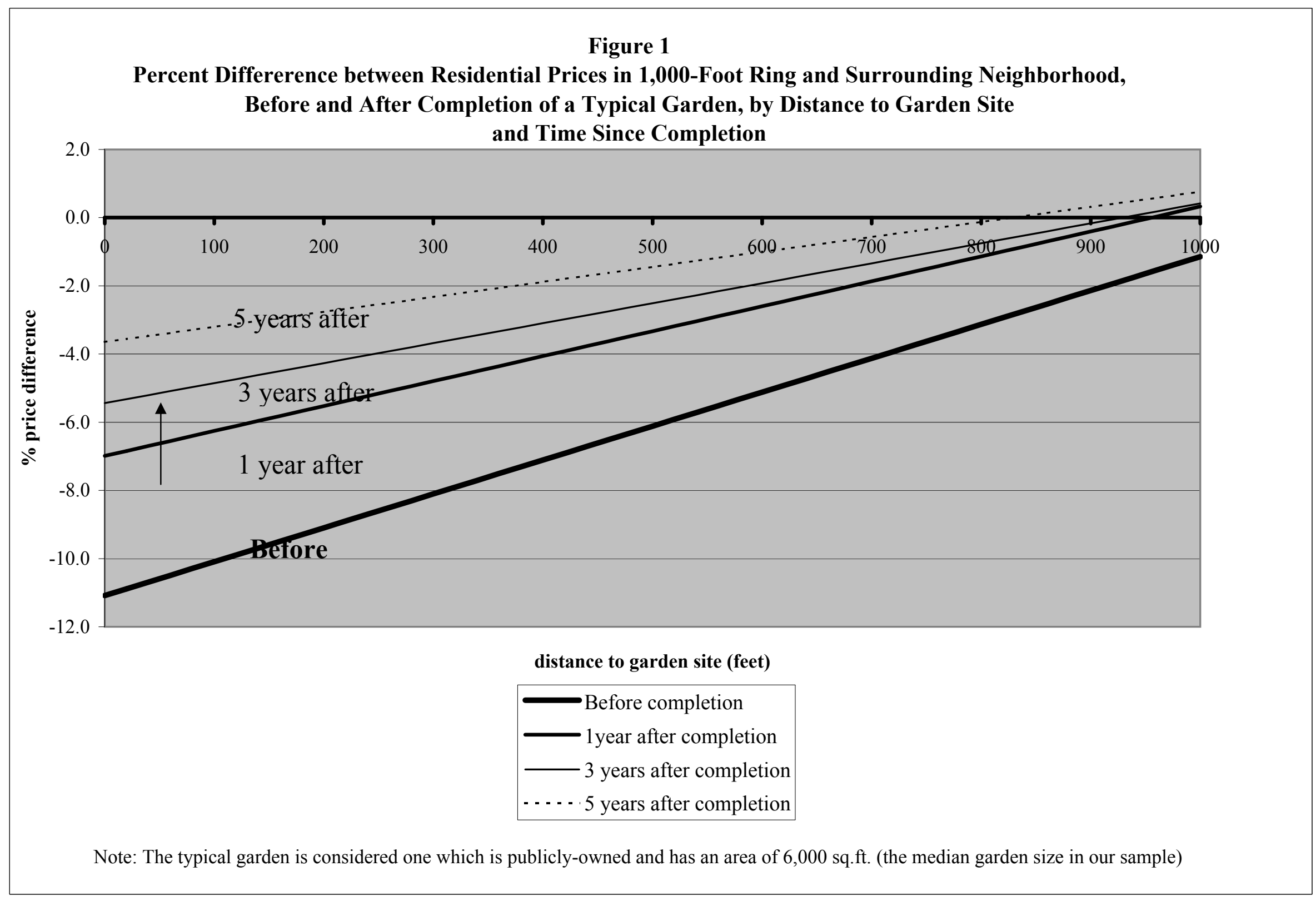


Table 1

Characteristics of Residential Properties Sold

\begin{tabular}{|c|c|c|}
\hline & $\begin{array}{l}\text { Percentage } \\
\text { of all } \\
\text { property } \\
\text { sales }\end{array}$ & $\begin{array}{l}\text { Percentage of sales } \\
\text { within } 1000 \text { feet of } \\
\text { community } \\
\text { garden sites }\end{array}$ \\
\hline \multicolumn{3}{|l|}{ Borough } \\
\hline Manhattan & 8.0 & 17.2 \\
\hline Bronx & 12.0 & 14.3 \\
\hline Brooklyn & 37.2 & 53.3 \\
\hline Queens & 37.4 & 14.6 \\
\hline Staten Island & 5.4 & 0.7 \\
\hline \multicolumn{3}{|l|}{ Building Class } \\
\hline Single-family detached & 21.8 & 10.0 \\
\hline Single-family attached & 13.9 & 9.0 \\
\hline Two-family & 33.1 & 31.6 \\
\hline Walk-up apartments & 18.1 & 31.5 \\
\hline Elevator apartments & 1.0 & 2.0 \\
\hline Loft buildings & 0.0 & 0.0 \\
\hline Condominiums & 7.7 & 9.2 \\
\hline $\begin{array}{l}\text { Mixed-use, primarily residential } \\
\text { (includes store or office plus residential units) }\end{array}$ & 4.3 & 6.7 \\
\hline \multicolumn{3}{|l|}{ Other Structural Characteristics } \\
\hline Built pre-World War II & 78.4 & 89.4 \\
\hline Vandalized & 0.0 & 0.2 \\
\hline Other abandoned & 0.1 & 0.3 \\
\hline Garage & 33.9 & 16.3 \\
\hline Corner location & 7.3 & 7.5 \\
\hline Major alteration prior to sale & 1.1 & 3.4 \\
\hline $\mathrm{N}$ & 517,791 & 77,642 \\
\hline
\end{tabular}

Note: Universe $=$ all sales in community districts with community gardens
Characteristics of Commercial Properties Sold

\begin{tabular}{|c|c|c|}
\hline & $\begin{array}{l}\text { Percentage } \\
\text { of all } \\
\text { property } \\
\text { sales }\end{array}$ & $\begin{array}{l}\text { Percentage of sales } \\
\text { within } 1000 \text { feet of } \\
\text { community } \\
\text { garden sites }\end{array}$ \\
\hline \multicolumn{3}{|l|}{ Borough } \\
\hline Manhattan & 11.9 & 16.8 \\
\hline Bronx & 16.1 & 20.6 \\
\hline Brooklyn & 44.0 & 53.8 \\
\hline Queens & 24.6 & 8.0 \\
\hline Staten Island & 3.4 & 0.8 \\
\hline \multicolumn{3}{|l|}{ Building Class } \\
\hline Industry & 24.6 & 25.0 \\
\hline Retail & 68.8 & 69.8 \\
\hline Office & 6.6 & 5.2 \\
\hline \multicolumn{3}{|c|}{ Other Structural Characteristics } \\
\hline Built pre-World War II & 76.5 & 84.7 \\
\hline Vandalized & 0.2 & 0.3 \\
\hline Other abandoned & 0.4 & 0.5 \\
\hline Garage & 4.1 & 2.2 \\
\hline Corner location & 27.4 & 26.9 \\
\hline Major alteration prior to sale & 5.8 & 6.2 \\
\hline $\mathrm{N}$ & 26,760 & 6,252 \\
\hline
\end{tabular}


Table 2. Subsidized Housing within 1000 feet of Community Gardens

\begin{tabular}{lrrrr}
\hline \multirow{2}{*}{ Program Type } & \multicolumn{4}{c}{ Units } \\
\cline { 2 - 5 } & \multicolumn{2}{c}{ within 1000 feet of garden } & \multicolumn{2}{c}{ total } \\
\cline { 2 - 5 } & \multicolumn{1}{c}{ Number } & \% of all residential & Number & \% of all residential \\
\hline Public housing & 90,189 & 14.1 & 169,569 & 7.1 \\
Other federally subsidized $^{1}$ & 50,257 & 7.9 & 90,068 & 3.7 \\
City-subsidized homeownership & 24,699 & 3.9 & 38,413 & 1.6 \\
City-subsidized rental $_{\text {Mitchell Lama rental }}^{93,914}$ & 14.7 & 163,746 & 6.8 \\
Mitchell Lama co-op $_{\text {All residential }}^{15,710}$ & 2.5 & 53,576 & 2.2 \\
\hline
\end{tabular}

1) Includes Sec. 8 NC/SR, Sec. 202, Sec. 236, BMIR, LIHTC

Note : Universe $=$ housing units in community districts with community gardens 
Table 3A. Descriptive statistics on New York City gardens

\begin{tabular}{lr}
\hline Garden area (x 1000 sq.ft.) & 35.5 \\
$\quad$ mean & 6.0 \\
median & \\
Completion year & 8.8 \\
\% established between 1977 and 1980 & 29.3 \\
\% established between 1981 and 1990 & 61.8 \\
\% established between 1991 and 2000 & \\
Land Ownership & 95.3 \\
\% public & 4.7 \\
\% private & \\
\% Borough & 27.2 \\
Manhattan & 23.1 \\
Bronx & 43.1 \\
Brooklyn & 6.1 \\
$\quad$ Queens & 0.5 \\
$\quad$ Staten Island & 636 \\
Number of gardens &
\end{tabular}

Table 3B. Descriptive statistics on surveyed gardens in the Bronx

Garden area (x 1000 sq.ft.)

mean

9.7

median

6.1

Completion year

$\%$ established between 1977 and $1980 \quad 8.2$

$\%$ established between 1981 and $1990 \quad 36.1$

$\%$ established between 1991 and $2000 \quad 55.8$

Land Ownership

$\%$ public

95.3

$\%$ private

Overall quality of garden

$\%$ gardens with acceptable overall quality ${ }^{1} \quad 76.7$

$\%$ gardens with acceptable overall quality ${ }^{2} \quad 60.5$

Detailed garden quality

$\%$ gardens with acceptable community access $\quad 67.4$

$\%$ gardens with acceptable fencing/security $\quad 64.0$

$\%$ gardens with acceptable cleanliness $\quad 55.8$

$\%$ gardens with acceptable landscaping $\quad 93.0$

$\%$ gardens with (non-seasonal) decorations $\quad 53.5$

$\%$ gardens with social spaces $\quad 34.9$

Number of gardens

86

1) Based on surveyor's assessment

2) Based on answers to all questions 
Table 4. 1980 Characteristics of Census Tracts with and without Gardens

\begin{tabular}{|c|c|c|}
\hline & $\begin{array}{l}\text { Tracts with } \\
\text { gardens }\end{array}$ & $\begin{array}{c}\text { Tracts without } \\
\text { gardens } \\
\text { but in SBA with gardens }\end{array}$ \\
\hline Mean family income & 29,649 & 45,593 \\
\hline Mean poverty rate & 36.7 & 18.8 \\
\hline Mean unemployment rate & 13.2 & 8.1 \\
\hline Mean homeownership rate & 12.7 & 31.5 \\
\hline Mean vacancy rate & 5.8 & 2.9 \\
\hline $\begin{array}{l}\text { Mean percentage of } 25+y r \text { old residents with } \\
\text { some college education }\end{array}$ & 16.8 & 25.2 \\
\hline Mean percentage black & 49.8 & 25.1 \\
\hline Mean percentage Hispanic & 31.8 & 18.8 \\
\hline Mean percentage foreign born & 17.9 & 24.0 \\
\hline Mean percentage kids (age $<5$ years) & 10.0 & 7.8 \\
\hline Mean percentage age $5-17$ & 23.2 & 18.4 \\
\hline Mean percentage age $18-64$ & 57.1 & 59.9 \\
\hline Mean percentage old (age $65+$ ) & 9.7 & 13.9 \\
\hline $\begin{array}{l}\text { Mean percentage of } 5+\mathrm{yr} \text { old people } \\
\text { who didn't change address within last } 5 \text { years }\end{array}$ & 57.3 & 61.0 \\
\hline $\mathrm{N}$ tracts & 308 & 1316 \\
\hline
\end{tabular}

Notes:

Tracts with less than 200 persons are excluded from the samples on which these statistics are based. 
Table 5. Selected Regression Results - Baseline Models

\begin{tabular}{|c|c|c|}
\hline & Residential & Commercial \\
\hline \multicolumn{3}{|l|}{ Ring variables } \\
\hline \multirow[t]{2}{*}{ In Ring } & $-0.1109^{* * *}$ & $-0.1847^{* * *}$ \\
\hline & $(0.0057)$ & $(0.0392)$ \\
\hline \multirow[t]{2}{*}{ In Ring * D } & $9.9 \mathrm{E}-05^{* * *}$ & $2.0 \mathrm{E}-04^{* * *}$ \\
\hline & $(7.4 \mathrm{E}-06)$ & $(4.9 \mathrm{E}-05)$ \\
\hline \multirow[t]{2}{*}{ Post Ring } & $0.0356^{* * *}$ & 0.0354 \\
\hline & $(0.0109)$ & $(0.0705)$ \\
\hline \multirow[t]{2}{*}{ Post Ring * D } & $-2.0 \mathrm{E}-05$ & $-4.2 \mathrm{E}-05$ \\
\hline & $(1.3 \mathrm{E}-05)$ & $(9.7 \mathrm{E}-05)$ \\
\hline \multirow[t]{2}{*}{ Garden area at the time of sale } & $-2.0 \mathrm{E}-04^{* * *}$ & $-1.8 \mathrm{E}-04$ \\
\hline & $(5.8 \mathrm{E}-05)$ & $(5.5 \mathrm{E}-04)$ \\
\hline \multirow[t]{2}{*}{ Garden area at the time of sale $* \mathrm{D}$} & $9.0 \mathrm{E}-08$ & $-2.7 \mathrm{E}-07$ \\
\hline & $(7.2 \mathrm{E}-08)$ & $(7.3 \mathrm{E}-07)$ \\
\hline \multirow[t]{2}{*}{$(\text { Garden area at the time of sale })^{2}$} & $6.4 \mathrm{E}-08^{*}$ & $5.7 \mathrm{E}-07$ \\
\hline & $(3.6 \mathrm{E}-08)$ & $(4.9 \mathrm{E}-07)$ \\
\hline \multirow[t]{2}{*}{ Share of privately owned land at the time of sale } & $-0.0282^{* * *}$ & -0.0935 \\
\hline & $(0.0091)$ & $(0.0729)$ \\
\hline \multirow[t]{2}{*}{ Tpost } & $0.0062^{* * *}$ & $0.0175^{* * *}$ \\
\hline & $(0.0023)$ & $(0.0062)$ \\
\hline \multirow[t]{2}{*}{ Tpost $* \mathrm{D}$} & $-7.3 \mathrm{E}-06^{* * *}$ & $-2.1 \mathrm{E}-05^{* *}$ \\
\hline & $(1.0 \mathrm{E}-06)$ & $(9.4 \mathrm{E}-06)$ \\
\hline \multirow[t]{2}{*}{ Tpost $^{2}$} & $4.5 \mathrm{E}-04^{* *}$ & \\
\hline & $(2.2 \mathrm{E}-04)$ & \\
\hline \multirow[t]{2}{*}{ Tpost $^{3}$} & $-1.6 \mathrm{E}-05^{* *}$ & \\
\hline & $(6.2 \mathrm{E}-06)$ & \\
\hline$\overline{\mathrm{N}}$ & 517,791 & 26,760 \\
\hline $\mathrm{R}^{2}$ & 0.8560 & 0.7838 \\
\hline
\end{tabular}

Note:

All regressions include census tract and community district-quarter dummies and the full set of building controls, as in the appendix.

Standard errors in parentheses. $* * *$ denotes $1 \%$ significance level; ** denotes $5 \%$ significance level;

* denotes $10 \%$ significance level. 
Table 6. Impacts of a Typical Garden on Residential Property Values (estimates based on median per-unit sales price of properties in rings)

\begin{tabular}{|c|c|c|c|c|c|c|}
\hline \multirow[b]{3}{*}{ Time since completior } & \multicolumn{6}{|c|}{ Distance to garden site (feet) } \\
\hline & \multicolumn{2}{|c|}{0} & \multicolumn{2}{|c|}{500} & \multicolumn{2}{|c|}{1000} \\
\hline & $\%$ & \$-value & $\%$ & \$-value & $\%$ & \$-value \\
\hline right after completion & 3.4 & 3,027 & 2.5 & 2,191 & 1.5 & 1,355 \\
\hline 1 year & 4.1 & 3,607 & 2.8 & 2,450 & 1.5 & 1,293 \\
\hline 3 years & 5.6 & 4,971 & 3.6 & 3,172 & 1.6 & 1,373 \\
\hline 5 years & 7.4 & 6,551 & 4.7 & 4,111 & 1.9 & 1,670 \\
\hline
\end{tabular}

Notes : \% impact is percentage point change in gap between prices in ring and outside;

$\$$-value impact is obtained by applying the \% impact to the median per-unit sales price of properties sold in rings. Median price per unit of properties sold in rings is $\$ 88,031$

The typical garden is considered one which is publicly-owned and has an area of 6,000 sq.ft. (the median garden size in our sample). 


\begin{tabular}{|c|c|c|c|c|}
\hline & \multicolumn{2}{|c|}{ Residential } & \multicolumn{2}{|c|}{ Commercial } \\
\hline & $\begin{array}{l}\text { High Income } \\
\text { Submarket }\end{array}$ & $\begin{array}{c}\text { Low Income - High Income } \\
\text { Differential } \\
\end{array}$ & $\begin{array}{l}\text { High Income } \\
\text { Submarket }\end{array}$ & $\begin{array}{c}\text { Low Income - High Income } \\
\text { Differential }\end{array}$ \\
\hline & & & & \\
\hline \multicolumn{5}{|l|}{ Ring variables } \\
\hline \multirow[t]{2}{*}{ In Ring } & $-0.0469^{* * *}$ & $-0.0930^{* * *}$ & $-0.2364^{* * *}$ & 0.0799 \\
\hline & $(0.0102)$ & $(0.0123)$ & $(0.0724)$ & $(0.0859)$ \\
\hline \multirow[t]{2}{*}{ In Ring * D } & $3.9 \mathrm{E}-05^{* * *}$ & $8.7 \mathrm{E}-05^{* * *}$ & $2.3 \mathrm{E}-04^{* *}$ & $-3.3 \mathrm{E}-05$ \\
\hline & $(1.3 \mathrm{E}-05)$ & $(1.6 \mathrm{E}-05)$ & $(9.3 \mathrm{E}-05)$ & $(1.1 \mathrm{E}-04)$ \\
\hline \multirow[t]{2}{*}{ Post Ring } & -0.0020 & $0.0570^{* *}$ & 0.1156 & -0.0983 \\
\hline & $(0.0206)$ & $(0.0243)$ & $(0.1531)$ & $(0.1726)$ \\
\hline \multirow[t]{2}{*}{ Post Ring * D } & $2.2 \mathrm{E}-05$ & $-6.4 \mathrm{E}-05^{* *}$ & $-1.4 \mathrm{E}-04$ & $1.0 \mathrm{E}-04$ \\
\hline & $(2.6 \mathrm{E}-05)$ & $(3.0 \mathrm{E}-05)$ & $(2.1 \mathrm{E}-04)$ & $(2.4 \mathrm{E}-04)$ \\
\hline \multirow[t]{2}{*}{ Garden area at the time of sale } & $-3.6 \mathrm{E}-04^{* * *}$ & $2.5 \mathrm{E}-04^{* *}$ & $-1.7 \mathrm{E}-03$ & $2.0 \mathrm{E}-03$ \\
\hline & $(9.6 \mathrm{E}-05)$ & $(1.2 \mathrm{E}-04)$ & $(1.8 \mathrm{E}-03)$ & $(1.9 \mathrm{E}-03)$ \\
\hline \multirow[t]{2}{*}{ Garden area at the time of sale * D } & $6.8 \mathrm{E}-08$ & 4.1E-08 & $7.5 \mathrm{E}-07$ & $-1.4 \mathrm{E}-06$ \\
\hline & $(1.0 \mathrm{E}-07)$ & $(1.4 \mathrm{E}-07)$ & $(1.5 \mathrm{E}-06)$ & $(1.8 \mathrm{E}-06)$ \\
\hline \multirow[t]{2}{*}{$(\text { Garden area at the time of sale })^{2}$} & $2.2 \mathrm{E}-07^{* * *}$ & $-2.4 \mathrm{E}-07^{* * *}$ & $3.4 \mathrm{E}-06$ & $-3.0 \mathrm{E}-06$ \\
\hline & $(5.8 \mathrm{E}-08)$ & $(7.4 \mathrm{E}-08)$ & $(4.1 \mathrm{E}-06)$ & $(4.1 \mathrm{E}-06)$ \\
\hline \multirow[t]{2}{*}{ Share of privately owned land at the time of sale } & $-0.0411^{* * *}$ & $0.0337^{*}$ & -0.0778 & -0.0213 \\
\hline & $(0.0154)$ & $(0.0192)$ & $(0.1121)$ & $(0.0001)$ \\
\hline \multirow[t]{2}{*}{ Tpost } & 0.0039 & 0.0032 & 0.0096 & 0.0096 \\
\hline & $(0.0043)$ & $(0.0051)$ & $(0.0126)$ & $(0.0145)$ \\
\hline \multirow[t]{2}{*}{ Tpost * D } & $-6.9 \mathrm{E}-06^{* * *}$ & 4.6E-07 & $-3.2 \mathrm{E}-05^{*}$ & $1.8 \mathrm{E}-05$ \\
\hline & $(2.1 \mathrm{E}-06)$ & $(2.4 \mathrm{E}-06)$ & $(1.8 \mathrm{E}-05)$ & $(2.1 \mathrm{E}-05)$ \\
\hline \multirow[t]{2}{*}{ Tpost $^{2}$} & $8.0 \mathrm{E}-04^{* *}$ & $-5.9 \mathrm{E}-04$ & & \\
\hline & $(4.1 \mathrm{E}-04)$ & $(4.8 \mathrm{E}-04)$ & & \\
\hline \multirow[t]{2}{*}{ Tpost $^{3}$} & $-3.1 \mathrm{E}-05^{* * *}$ & $2.5 \mathrm{E}-05^{*}$ & & \\
\hline & $(1.2 \mathrm{E}-05)$ & $(1.4 \mathrm{E}-05)$ & & \\
\hline $\mathrm{N}$ & & 517791 & & 26760 \\
\hline $\mathrm{R}^{2}$ & & 0.8576 & & 0.7843 \\
\hline
\end{tabular}

Note:

Coefficients in columns (2) and (4) correpond to a set of interactions between the ring variables and a dummy which is equal to 1 for the low income submarket and 0 otherwise. The low income submarket comprises community districts for which the CD/MSA mean household income ratio is smaller than 0.8 (and the high income submarket includes all the other community districts).

The regressions include census tract and CD-quarter dummies, and the full set of building controls and their interactions with the low income submarket dummy.

Standard errors in parentheses. $* * *$ denotes $1 \%$ significance level; $* *$ denotes $5 \%$ significance level; * denotes $10 \%$ significance level. 
Table 8. Baseline Models based on Survey Samples

\begin{tabular}{|c|c|c|}
\hline & Residential & Commercial \\
\hline \multicolumn{3}{|l|}{ Ring variables } \\
\hline \multirow[t]{2}{*}{ In Ring } & $-0.1219^{* * *}$ & $-0.3089^{* *}$ \\
\hline & $(0.0178)$ & $(0.1304)$ \\
\hline \multirow[t]{2}{*}{ In Ring * D } & $1.0 \mathrm{E}-04^{* * *}$ & $5.3 \mathrm{E}-04^{* * *}$ \\
\hline & $(2.3 \mathrm{E}-05)$ & $(1.7 \mathrm{E}-04)$ \\
\hline \multirow[t]{2}{*}{ Post Ring } & $0.1016^{* * *}$ & 0.0211 \\
\hline & $(0.0292)$ & $(0.2403)$ \\
\hline \multirow[t]{2}{*}{ Post Ring * D } & $-1.1 \mathrm{E}-04^{* * *}$ & $1.1 \mathrm{E}-04$ \\
\hline & $(3.6 \mathrm{E}-05)$ & $(3.2 \mathrm{E}-04)$ \\
\hline \multirow[t]{2}{*}{ Garden area at the time of sale } & $-0.0021^{* *}$ & 4.8E-04 \\
\hline & $(8.9 \mathrm{E}-04)$ & $(7.9 \mathrm{E}-03)$ \\
\hline \multirow[t]{2}{*}{ Garden area at the time of sale $* D$} & $-7.1 \mathrm{E}-07$ & $-1.9 \mathrm{E}-05^{* *}$ \\
\hline & $(8.6 \mathrm{E}-07)$ & $(8.6 \mathrm{E}-06)$ \\
\hline \multirow[t]{2}{*}{$(\text { Garden area at the time of sale })^{2}$} & $1.6 \mathrm{E}-05^{* * *}$ & $1.1 \mathrm{E}-04^{* *}$ \\
\hline & $(5.5 \mathrm{E}-06)$ & $(5.0 \mathrm{E}-05)$ \\
\hline \multirow[t]{2}{*}{ Share of privately owned land at the time of sale } & -0.0501 & 0.0277 \\
\hline & $(0.0000)$ & $(0.0002)$ \\
\hline \multirow[t]{2}{*}{ Tpost } & $0.0125^{* *}$ & 0.0310 \\
\hline & $(0.0062)$ & $(0.0198)$ \\
\hline \multirow[t]{2}{*}{ Tpost * D } & $1.6 \mathrm{E}-06$ & $-3.7 \mathrm{E}-05$ \\
\hline & $(2.8 \mathrm{E}-06)$ & $(2.8 \mathrm{E}-05)$ \\
\hline \multirow[t]{2}{*}{ Tpost $^{2}$} & $-0.0012^{* *}$ & \\
\hline & $(6.0 \mathrm{E}-04)$ & \\
\hline \multirow[t]{2}{*}{ Tpost $^{3}$} & $3.6 \mathrm{E}-05^{* *}$ & \\
\hline & $(1.7 \mathrm{E}-05)$ & \\
\hline $\mathrm{N}$ & 61,880 & 4,298 \\
\hline $\mathrm{R}^{2}$ & 0.8756 & 0.6682 \\
\hline
\end{tabular}

Note:

All regressions include census tract and community district-quarter dummies and the full set of building controls.

Standard errors in parentheses. $* * *$ denotes $1 \%$ significance level; ** denotes $5 \%$ significance level;

* denotes $10 \%$ significance level. 
Table 9. Models with Overall Quality of Garden

Residential Commercial

\begin{tabular}{|c|c|c|}
\hline \multirow{2}{*}{\multicolumn{3}{|c|}{ Ring variables }} \\
\hline & & \\
\hline \multirow[t]{2}{*}{ In Ring } & $-0.0653^{* * *}$ & -0.0429 \\
\hline & $(0.0212)$ & $(0.1482)$ \\
\hline \multirow[t]{2}{*}{ In Ring * D } & $9.5 \mathrm{E}-05^{* * *}$ & 4.7E-0 $04^{* * *}$ \\
\hline & $(2.3 \mathrm{E}-05)$ & $(1.7 \mathrm{E}-04)$ \\
\hline \multicolumn{3}{|l|}{ Overall quality of future or existing gardens } \\
\hline \multirow[t]{2}{*}{ Share of existing or future garden area with acceptable quality } & $-0.0797^{* * *}$ & $-0.3691^{* * *}$ \\
\hline & $(0.0160)$ & $(0.0979)$ \\
\hline \multirow[t]{2}{*}{ Post Ring } & 0.0500 & -0.0717 \\
\hline & $(0.0313)$ & $(0.2545)$ \\
\hline \multirow[t]{2}{*}{ Post Ring * D } & $-1.1 \mathrm{E}-04^{* * *}$ & $1.3 \mathrm{E}-04$ \\
\hline & $(3.6 \mathrm{E}-05)$ & (3.1E-04) \\
\hline \multirow[t]{2}{*}{ Garden area at the time of sale } & $-2.0 \mathrm{E}-03^{* *}$ & $-2.0 \mathrm{E}-03$ \\
\hline & $(8.9 \mathrm{E}-04)$ & $(8.0 \mathrm{E}-03)$ \\
\hline \multirow[t]{2}{*}{ Garden area at the time of sale * D } & $-7.4 \mathrm{E}-07$ & $-1.8 \mathrm{E}-05^{* *}$ \\
\hline & (8.6E-07) & $(8.6 \mathrm{E}-06)$ \\
\hline \multirow[t]{2}{*}{$(\text { Garden area at the time of sale })^{2}$} & $1.6 \mathrm{E}-05^{* * *}$ & $1.2 \mathrm{E}-04^{* *}$ \\
\hline & $(5.5 \mathrm{E}-06)$ & $(5.0 \mathrm{E}-05)$ \\
\hline \multirow[t]{2}{*}{ Share of privately owned land at the time of sale } & -0.0393 & -0.0348 \\
\hline & $(0.0333)$ & $(0.2392)$ \\
\hline \multirow[t]{2}{*}{ Tpost } & $0.0129^{* *}$ & $0.0345 *$ \\
\hline & $(0.0062)$ & $(0.0198)$ \\
\hline \multirow[t]{2}{*}{ Tpost $* \mathrm{D}$} & $1.9 \mathrm{E}-06$ & $-4.0 \mathrm{E}-05$ \\
\hline & $(2.8 \mathrm{E}-06)$ & $(2.8 \mathrm{E}-05)$ \\
\hline \multirow[t]{2}{*}{ Tpost $^{2}$} & $-1.3 \mathrm{E}-03^{* *}$ & \\
\hline & $(6.0 \mathrm{E}-04)$ & \\
\hline \multirow[t]{2}{*}{ Tpost $^{3}$} & $3.9 \mathrm{E}-05^{* *}$ & \\
\hline & $(1.7 \mathrm{E}-05)$ & \\
\hline \multicolumn{3}{|l|}{ Overall quality of existing gardens at the time of sale } \\
\hline \multirow[t]{2}{*}{ Share of existing garden area with acceptable quality } & $0.0780^{* * *}$ & 0.1448 \\
\hline & $(0.0167)$ & $(0.1179)$ \\
\hline $\mathrm{N}$ & 61,880 & 4,298 \\
\hline $\mathrm{R}^{2}$ & 0.8756 & 0.6698 \\
\hline
\end{tabular}

Note:

All regressions include census tract and community district-quarter dummies and the full set of building controls.

Standard errors in parentheses. ${ }^{* * *}$ denotes $1 \%$ significance level; $* *$ denotes $5 \%$ significance level;

$*$ denotes $10 \%$ significance level. 
Table 10. Models with Specific Quality Features

\begin{tabular}{|c|c|c|}
\hline & Residential & Commercial \\
\hline \multicolumn{3}{|l|}{ Ring variables } \\
\hline \multirow[t]{2}{*}{ In Ring } & $-0.1014^{* * *}$ & -0.0552 \\
\hline & $(0.0201)$ & $(0.1448)$ \\
\hline \multirow[t]{2}{*}{ In Ring * D } & $1.0 \mathrm{E}-04^{* * *}$ & 4.9E-04 ${ }^{* * *}$ \\
\hline & $(2.3 \mathrm{E}-05)$ & $(1.7 \mathrm{E}-04)$ \\
\hline \multicolumn{3}{|l|}{ Overall quality of future or existing garden } \\
\hline \multirow[t]{2}{*}{ Share of existing or future garden area with acceptable quality } & $-0.0351^{* * *}$ & $-0.3436^{* * *}$ \\
\hline & $(0.0137)$ & $(0.0901)$ \\
\hline \multirow[t]{2}{*}{ Post Ring } & 0.0404 & -0.2014 \\
\hline & $(0.0341)$ & $(0.3161)$ \\
\hline \multirow[t]{2}{*}{ Post Ring * D } & $-1.1 \mathrm{E}-04^{* * *}$ & $1.5 \mathrm{E}-04$ \\
\hline & $(3.7 \mathrm{E}-05)$ & $(3.1 \mathrm{E}-04)$ \\
\hline \multirow[t]{2}{*}{ Garden area at the time of sale } & $-2.4 \mathrm{E}-03^{* * *}$ & $-2.1 \mathrm{E}-04$ \\
\hline & $(9.0 \mathrm{E}-04)$ & $(8.2 \mathrm{E}-03)$ \\
\hline \multirow[t]{2}{*}{ Garden area at the time of sale * D } & $-9.4 \mathrm{E}-07$ & $-2.0 \mathrm{E}-05^{* *}$ \\
\hline & $(8.6 \mathrm{E}-07)$ & $(8.6 \mathrm{E}-06)$ \\
\hline \multirow[t]{2}{*}{$(\text { Garden area at the time of sale })^{2}$} & $1.6 \mathrm{E}-05^{* * *}$ & $1.3 \mathrm{E}-04^{* * *}$ \\
\hline & $(5.6 \mathrm{E}-06)$ & $(5.0 \mathrm{E}-05)$ \\
\hline \multirow[t]{2}{*}{ Share of privately owned land at the time of sale } & -0.0167 & 0.1481 \\
\hline & $(0.0351)$ & $(0.2745)$ \\
\hline \multirow[t]{2}{*}{ Tpost } & $0.0110^{*}$ & $0.0348^{*}$ \\
\hline & $(0.0062)$ & $(0.0199)$ \\
\hline \multirow[t]{2}{*}{ Tpost $* \mathrm{D}$} & $1.2 \mathrm{E}-06$ & $-4.2 \mathrm{E}-05$ \\
\hline & $(2.8 \mathrm{E}-06)$ & $(2.8 \mathrm{E}-05)$ \\
\hline \multirow[t]{2}{*}{ Tpost $^{2}$} & $-1.1 \mathrm{E}-03 *$ & \\
\hline & $(6.0 \mathrm{E}-04)$ & \\
\hline \multirow[t]{2}{*}{ Tpost $^{3}$} & $3.3 \mathrm{E}-05 *$ & \\
\hline & $(1.7 \mathrm{E}-05)$ & \\
\hline \multicolumn{3}{|l|}{ Detailed garden quality at the time of sale } \\
\hline \multirow[t]{2}{*}{ Share of existing garden area with acceptable community access } & 0.0078 & -0.0562 \\
\hline & $(0.0196)$ & $(0.1403)$ \\
\hline \multirow[t]{2}{*}{ Share of existing garden area with acceptable fencing/security } & $0.0295^{*}$ & 0.1490 \\
\hline & $(0.0155)$ & $(0.1052)$ \\
\hline \multirow[t]{2}{*}{ Share of existing garden area with acceptable cleanliness } & $0.0382^{* *}$ & 0.0868 \\
\hline & $(0.0194)$ & $(0.0994)$ \\
\hline \multirow[t]{2}{*}{ Share of existing garden area with acceptable landscaping } & $0.0575^{* *}$ & -0.1555 \\
\hline & $(0.0251)$ & $(0.2212)$ \\
\hline \multirow[t]{2}{*}{ Share of existing garden area with (non-seasonal) decorations } & -0.0184 & $0.3473^{* * *}$ \\
\hline & $(0.0144)$ & $(0.1125)$ \\
\hline \multirow[t]{2}{*}{ Share of existing garden area with social spaces } & -0.0094 & 0.0388 \\
\hline & $(0.0151)$ & $(0.1177)$ \\
\hline $\mathrm{N}$ & 61,880 & 4,298 \\
\hline $\mathrm{R}^{2}$ & 0.8756 & 0.6707 \\
\hline
\end{tabular}

Note:

All regressions include census tract and community district-quarter dummies and the full set of building controls. Standard errors in parentheses. $* * *$ denotes $1 \%$ significance level; ** denotes 5\% significance level; * denotes $10 \%$ significance level. 
APPENDIX

Table A1. Complete Regression Results for Baseline Model

\begin{tabular}{|c|c|c|c|}
\hline \multicolumn{2}{|l|}{ Residential } & \multicolumn{2}{|l|}{ Commercial } \\
\hline $\begin{array}{l}\text { Ring variables } \\
\text { In Ring } \\
\text { In Ring * D }\end{array}$ & $\begin{array}{c}-0.1109^{\cdots \cdots} \\
(0.0057) \\
9.9 \mathrm{E}-05^{\cdots \cdots} \\
(7.4 \mathrm{E}-06)\end{array}$ & $\begin{array}{l}\text { Ring variables } \\
\text { In Ring } \\
\text { In Ring * D }\end{array}$ & $\begin{array}{c}-0.1847^{\cdots \cdots} \\
(0.0392) \\
2.0 \mathrm{E}-04^{\cdots \cdots} \\
(4.9 \mathrm{E}-05)\end{array}$ \\
\hline Post Ring & $\begin{array}{c}0.0356^{* * *} \\
(0.0109)\end{array}$ & Post Ring & $\begin{array}{r}0.0354 \\
(0.0705)\end{array}$ \\
\hline Post Ring * D & $\begin{array}{r}-2.0 \mathrm{E}-05 \\
(1.3 \mathrm{E}-05)\end{array}$ & Post Ring * D & $\begin{array}{r}-4.2 \mathrm{E}-05 \\
(9.7 \mathrm{E}-05)\end{array}$ \\
\hline Garden area at the time of sale & $\begin{array}{l}-2.0 \mathrm{E}-04 \\
(5.8 \mathrm{E}-05)\end{array}$ & Garden area at the time of sale & $\begin{array}{r}-1.8 \mathrm{E}-04 \\
(5.5 \mathrm{E}-04)\end{array}$ \\
\hline Garden area at the time of sale * D & $\begin{array}{r}9.0 \mathrm{E}-08 \\
(7.2 \mathrm{E}-08)\end{array}$ & Garden area at the time of sale * D & $\begin{array}{r}-2.7 \mathrm{E}-07 \\
(7.3 \mathrm{E}-07)\end{array}$ \\
\hline$(\text { Garden area at the time of sale })^{2}$ & $\begin{array}{r}6.4 \mathrm{E}-08 \\
(3.6 \mathrm{E}-08)\end{array}$ & $(\text { Garden area at the time of sale })^{2}$ & $\begin{array}{r}5.7 \mathrm{E}-07 \\
(4.9 \mathrm{E}-07)\end{array}$ \\
\hline Share of privately owned land at the time of sale & $\begin{array}{l}-0.0282 \\
(0.0091)\end{array}$ & Share of privately owned land at the time of sale & $\begin{array}{r}-0.0935 \\
(0.0729)\end{array}$ \\
\hline Tpost & $\begin{array}{l}0.0062^{* * *} \\
(0.0023)\end{array}$ & Tpost & $\begin{array}{l}0.0175^{* * *} \\
(0.0062)\end{array}$ \\
\hline Tpost * D & $\begin{array}{l}-7.3 \mathrm{E}-06^{* * *} \\
(1.0 \mathrm{E}-06)\end{array}$ & Tpost $* \mathrm{D}$ & $\begin{array}{l}-2.1 \mathrm{E}-05^{* *} \\
(9.4 \mathrm{E}-06)\end{array}$ \\
\hline Tpost $^{2}$ & $\begin{array}{l}4.5 \mathrm{E}-04^{* *} \\
(2.2 \mathrm{E}-04)\end{array}$ & & \\
\hline Tpost $^{3}$ & $\begin{array}{l}-1.6 \mathrm{E}-05^{* *} \\
(6.2 \mathrm{E}-06)\end{array}$ & & \\
\hline Ring variables for gardens with invalid completion ye & & Ring variables for gardens with invalid completion year & \\
\hline In Ring & $\begin{array}{l}-0.0201 \\
(0.0105)\end{array}$ & In Ring & $\begin{array}{r}0.0035 \\
(0.0733)\end{array}$ \\
\hline Post Ring & $\begin{array}{r}0.0078 \\
(0.0107)\end{array}$ & Post Ring & $\begin{array}{r}-0.0854 \\
(0.0753)\end{array}$ \\
\hline Garden area at the time of sale & $\begin{array}{l}-3.4 \mathrm{E}-07 \\
(4.3 \mathrm{E}-08) \\
\end{array}$ & Garden area at the time of sale & $\begin{array}{r}-1.4 \mathrm{E}-07 \\
(4.2 \mathrm{E}-07) \\
\end{array}$ \\
\hline Characteristics of properties sold & & Characteristics of properties sold & \\
\hline Vandalized & $\begin{array}{l}-0.0771^{* * *} \\
(0.0243)\end{array}$ & Vandalized & $\begin{array}{l}-0.2856^{* * *} \\
(0.1008)\end{array}$ \\
\hline Other abandoned & $\begin{array}{l}-0.0868^{* * *} \\
(0.0138)\end{array}$ & Other abandoned & $\begin{array}{l}-0.2083^{* * *} \\
(0.0717)^{4}\end{array}$ \\
\hline Odd shape & $\begin{array}{l}0.0225^{* * *} \\
(0.0017)\end{array}$ & Odd shape & $\begin{array}{l}0.0977^{* * *} \\
(0.0095)\end{array}$ \\
\hline Garage & ${ }^{0.0491} 1^{* * *}$ & Garage & $\begin{array}{l}-0.0592^{* * *} \\
(0.0214)\end{array}$ \\
\hline Extension & $\begin{array}{l}0.0484^{* * *} \\
(0.0016)\end{array}$ & Extension & $\begin{array}{r}0.0114 \\
(0.0116)\end{array}$ \\
\hline Corner & $\begin{array}{c}0.0493^{* * *} \\
(0.0018)\end{array}$ & Corner & $\begin{array}{l}0.1366^{* * *} \\
(0.0095)\end{array}$ \\
\hline Major alteration prior to sale & $\begin{array}{l}0.0454^{* * *} \\
(0.0048)\end{array}$ & Major alteration prior to sale & $\begin{array}{l}0.1584^{* * *} \\
(0.0190)\end{array}$ \\
\hline Age of unit & $\begin{array}{l}-0.0103^{* * *} \\
(0.0001)^{2}\end{array}$ & Age of unit & $\begin{array}{l}-0.0088^{* * *} \\
(0.0006)\end{array}$ \\
\hline (Age of unit)2 & $\begin{array}{l}6.8 \mathrm{E}-05^{* * *} \\
(8.4 \mathrm{E}-07)\end{array}$ & (Age of unit)2 & $\begin{array}{r}4.0 \mathrm{E}-05^{* * *} \\
(5.1 \mathrm{E}-06)\end{array}$ \\
\hline Age of unit missing & $\begin{array}{l}-0.2148^{* * *} \\
(0.0042)\end{array}$ & Age of unit missing & $\begin{array}{l}-0.4283^{* * *} \\
(0.0301)^{2 *}\end{array}$ \\
\hline Log square feet per unit & $\begin{array}{r}0.4120^{* * *} \\
(0.0016)\end{array}$ & Log square feet & $\begin{array}{l}0.4813^{* * *} \\
(0.0083)\end{array}$ \\
\hline Number of buildings on same lot & $\begin{array}{l}-0.0410^{* * *} \\
(0.0027)\end{array}$ & Square feet missing & $\begin{array}{l}3.1427^{* * *} \\
(0.0735)\end{array}$ \\
\hline
\end{tabular}


Table A1. Complete Regression Results for Baseline Model (continued)

\begin{tabular}{|c|c|c|c|}
\hline \multicolumn{2}{|l|}{ Residential } & \multicolumn{2}{|c|}{ Commercial } \\
\hline Includes commercial space & $\begin{array}{c}0.0284^{* * *} \\
(0.0051)\end{array}$ & Log number of stories & $\begin{array}{l}-0.0491 \\
(0.0118)\end{array}$ \\
\hline Square feet missing & $\begin{array}{l}2.8896^{* * *} \\
(0.0200)\end{array}$ & Log frontage & $\begin{array}{l}0.2483^{* * *} \\
(0.0116)\end{array}$ \\
\hline Condo and square feet missing & $\begin{array}{l}-0.1123^{* * *} \\
(0.0170)\end{array}$ & Commercial ratio on the block & $\begin{array}{c}0.0022^{* * *} \\
(0.0002)\end{array}$ \\
\hline Single-family detached & $\begin{array}{l}0.08811^{* * *} \\
(0.0017)\end{array}$ & Retail & $\begin{array}{c}0.07222^{* * *} \\
(0.0121)\end{array}$ \\
\hline Two-family home & $\begin{array}{l}-0.3354^{* * *} \\
(0.0017)\end{array}$ & Office & $\begin{array}{r}0.2942^{* * *} \\
(0.0214) \\
\end{array}$ \\
\hline Three-family home & $\begin{array}{l}-0.5773^{* * *} \\
(0.0022)\end{array}$ & $\frac{\mathrm{N}}{\mathrm{R}^{2}}$ & $\begin{array}{c}26,760 \\
0.7838\end{array}$ \\
\hline Four-family home & $\begin{array}{l}-0.7579^{* * *} \\
(0.0034)\end{array}$ & & \\
\hline Five/six-family home & $\begin{array}{l}-1.1274^{* * *} \\
(0.0039)\end{array}$ & & \\
\hline More than six families, no elevator & $\begin{array}{l}-1.52111^{* * *} \\
(0.0040)\end{array}$ & & \\
\hline Walkup, units not specified & $\begin{array}{l}-1.3727^{* * *} \\
(0.0054)\end{array}$ & & \\
\hline Elevator apartment building, cooperatives & $\begin{array}{l}-1.3830 \\
(0.0092)\end{array}$ & & \\
\hline Elevator apartment building, not cooperatives & $\begin{array}{l}-1.51011^{* * *} \\
(0.0061)\end{array}$ & & \\
\hline Loft building & $\begin{array}{l}-0.7708 \text { *** } \\
(0.0244)\end{array}$ & & \\
\hline Condominium, single-family attached & $\begin{array}{l}-0.2395^{* * *} \\
(0.0113)\end{array}$ & & \\
\hline Condominium, walk-up apartments & $\begin{array}{l}-0.24466^{* * *} \\
(0.0054)\end{array}$ & & \\
\hline Condominium, elevator building & $\begin{array}{l}-0.5052^{* * *} \\
(0.0050)\end{array}$ & & \\
\hline Condominium, miscellaneous & $\begin{array}{l}-0.7777^{* * *} \\
(0.0102)\end{array}$ & & \\
\hline Multi-use, single family with store & $\begin{array}{l}-0.0865^{* * *} \\
(0.0071)\end{array}$ & & \\
\hline Multi-use, two-family with store & $\begin{array}{l}-0.5488^{* * *} \\
(0.0062)\end{array}$ & & \\
\hline Multi-use, three-family with store & $\begin{array}{l}-0.7706^{* * *} \\
(0.0086)\end{array}$ & & \\
\hline Multi-use, four or more family with store & $\begin{array}{l}-0.9609^{* * *} \\
(0.0067)\end{array}$ & & \\
\hline $\mathrm{N}$ & 517,791 & & \\
\hline $\mathrm{R}^{2}$ & 0.8560 & & \\
\hline te: & & & \\
\hline
\end{tabular}


Table A2. Impacts of a Typical Garden on Residential Property Values (estimates based on mean per-unit sales price of properties in rings)

\begin{tabular}{|c|c|c|c|c|c|c|}
\hline \multirow[b]{3}{*}{ Time since completior } & \multicolumn{6}{|c|}{ Distance to garden site (feet) } \\
\hline & \multicolumn{2}{|c|}{0} & \multicolumn{2}{|c|}{500} & \multicolumn{2}{|c|}{1000} \\
\hline & $\%$ & \$-value & $\%$ & \$-value & $\%$ & $\$$-value \\
\hline right after completion & 3.4 & 4,308 & 2.5 & 3,118 & 1.5 & 1,928 \\
\hline 1 year & 4.1 & 5,134 & 2.8 & 3,487 & 1.5 & 1,840 \\
\hline 3 years & 5.6 & 7,074 & 3.6 & 4,514 & 1.6 & 1,954 \\
\hline 5 years & 7.4 & 9,323 & 4.7 & 5,850 & 1.9 & 2,377 \\
\hline
\end{tabular}

Notes : \% impact is percentage point change in gap between prices in ring and outside;

$\$$-value impact is obtained by applying the \% impact to the average per-unit sales price of properties sold in rings. Average price per unit of properties sold in rings is $\$ 125,275$.

The typical garden is considered one which is publicly-owned and has an area of 6,000 sq.ft. (the median garden size in our sample). 
Table A3. Impacts of a Typical Garden on Residential Property Values in Low- and High-Income Neighborhoods (estimates based on median per-unit sales price of properties in rings)

\begin{tabular}{|c|c|c|c|c|c|c|c|c|c|c|c|c|}
\hline \multirow[b]{4}{*}{ Time since completior } & \multicolumn{6}{|c|}{ Low-income submarket } & \multicolumn{6}{|c|}{ High-income submarket } \\
\hline & \multicolumn{6}{|c|}{ Distance to garden site (feet) } & \multicolumn{6}{|c|}{ Distance to garden site (feet) } \\
\hline & \multicolumn{2}{|c|}{0} & \multicolumn{2}{|c|}{500} & \multicolumn{2}{|c|}{1000} & \multicolumn{2}{|c|}{0} & \multicolumn{2}{|c|}{500} & \multicolumn{2}{|c|}{1000} \\
\hline & $\%$ & \$-value & $\%$ & \$-value & $\%$ & \$-value & $\%$ & \$-value & $\%$ & \$-value & $\%$ & \$-value \\
\hline right after completion & 5.4 & 4,777 & 3.3 & 2,939 & 1.3 & 1,101 & -0.4 & -371 & 0.7 & 605 & 1.8 & 1,580 \\
\hline 1 year & 6.2 & 5,421 & 3.8 & 3,301 & 1.3 & 1,182 & 0.0 & 43 & 0.8 & 717 & 1.6 & 1,390 \\
\hline 3 years & 7.7 & 6,806 & 4.7 & 4,124 & 1.6 & 1,442 & 1.4 & 1,228 & 1.5 & 1,298 & 1.6 & 1,369 \\
\hline 5 years & 9.4 & 8,300 & 5.7 & 5,056 & 2.1 & 1,811 & 3.2 & 2,781 & 2.6 & 2,248 & 1.9 & 1,716 \\
\hline
\end{tabular}

Notes : \% impact is percentage point change in gap between prices in ring and outside; \$-value impact is obtained by applying the \% impact to the median per-unit sales price of properties sold in rings. Median price per unit of properties sold in rings is $\$ 88,031$.

The typical garden is considered one which is publicly-owned and has an area of 6,000 sq.ft. (the median garden size in our sample). 
Table A4. Alternative Models with Overall Quality of Garden

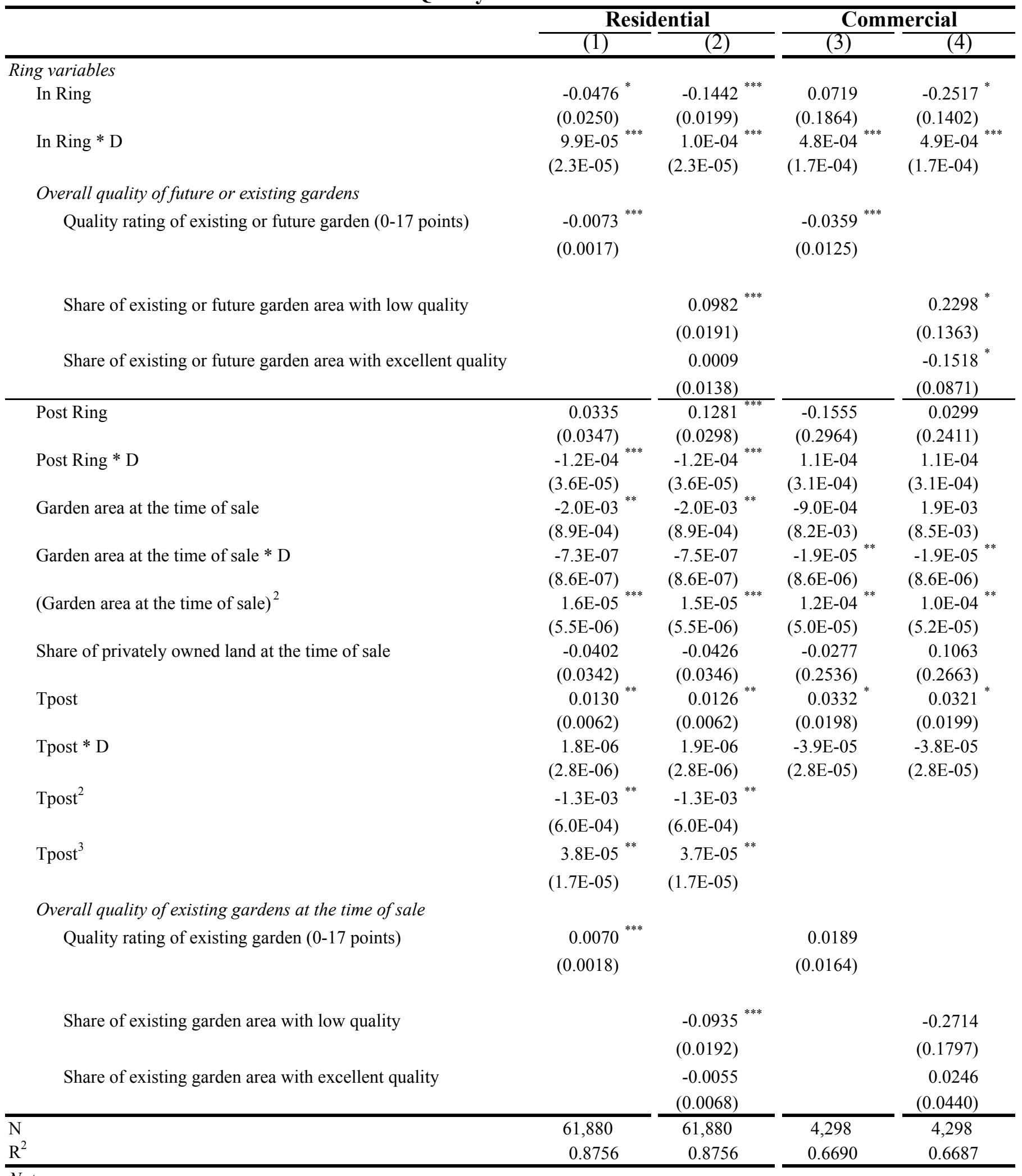

Note:

All regressions include census tract and community district-quarter dummies and the full set of building controls.

Standard errors in parentheses. $* * *$ denotes $1 \%$ significance level; ** denotes $5 \%$ significance level; * denotes $10 \%$ significance level. 


\section{SURVEY QUESTIONAIRE}

\section{Garden Name:}

Garden Address:

Identifying Information. If the name posted on the garden, or the location of the garden differs from the information we have provided to you, please note that information here:

Name:

Location Description:

Type of Garden. Please check ONE of the following.

IS a community garden:

- Greenspace, with individual garden plots

- Greenspace, without individual garden plots.

NOT a community garden:

- Vacant/abandoned open space

- School Found, Garden not found

- Building, under construction

- Building, completed

- Other:

Community Accessibility. Please check ALL that apply.

․ Is there information about when the garden is open to visitors?

Please list days/times/seasons the garden is open to the public if it is posted:

- Is there information about how community members can become involved with the garden?

- Is there information suggesting an affiliation with a special program or organization?

口 Green Thumb

- Green Guerillas

- New York Restoration Project

a Other:

Decorations. Please check ALL that apply.

․ Are there seasonal decorations?

․ Are there other decorations? 
Fencing. Please check ALL that apply.

․ Is the fence secure?

- Does the fence have special permanent features?

Is the fence visually appealing?

口 Is the entrance well-demarcated?

Cleanliness. Please check ALL that apply.

- Is there litter/trash inside the garden's fence (not in receptacle)?

- Is there litter/trash on the sidewalk in front of the garden (not in receptacle)?

- Are there trash receptacles in the garden?

- Are there receptacles designated for recycling?

a Is there evidence of dumping or that the garden is being used for furniture/appliance storage?

- Are tools stored in neat and orderly manner?

․ Is there broken glass, condoms, dead animals, or drug paraphernalia?

I Is there graffiti?

․ Is the garden relatively free of weeds?

Garden Plots. Please check ALL that apply.

- Are garden beds bordered or raised?

口 Are all the beds planted? If not, are unplanted beds tidy, or covered with mulch, or fabric/plastic?

- Are any plantings in bloom?

․ Are there permanent plantings?

Social Spaces. Please check ALL that apply.

- Is there an orderly, uns heltered gathering area?

- Is there an orderly, semi- sheltered gathering area?

- Is there an orderly, fully- sheltered gathering area?

I Is there a BBQ grill or gas stove?

․ Is there a play area for children?

Overall Assessment. Assume a new Community Garden is going to be installed in your neighborhood. How much would you like the new CG to be just like this? Circle one choice, on a scale of 1 to 5 . 